\title{
LA PROTECCIÓ DELS DRETS FONAMENTALS CONTRA LA CONTAMINACIÓ ACÚSTICA EN LA JURISPRUDÈNCIA CONTENCIOSA ADMINISTRATIVA, CIVIL I PENAL
}

\author{
Francesc Claverol Guiu \\ Advocat de la Generalitat de Catalunya
}

Tècnic del Cos Superior de la Generalitat de Catalunya, àmbit jurídic, en excedència cesccla24@gmail.com

Rebut: 5 d'octubre de 2015 / Acceptat: 29 de març de 2016

RESUM: En la nostra societat, tecnològicament avançada, amb una notable densitat de població i amb un augment dels estàndards de qualitat de vida, el soroll és un problema cada cop més present, al qual, la jurisprudència, tant en l'ordre contenciós administratiu com en el civil i en el penal, ha hagut de donar resposta, seguint la línia fixada pel Tribunal Europeu de Drets Humans i el Tribunal Constitucional espanyol.

RESUMEN: En nuestra sociedad, tecnológicamente avanzada, con una notable densidad de población y con un aumento de los estándares de calidad de vida, el ruido es un problema cada vez más presente, al cual la jurisprudencia, tanto en el orden contencioso administrativo como en el civil y en el penal, ha tenido que dar respuesta, siguiendo la línea fijada por el Tribunal Europeo de Derechos Humanos y el Tribunal Constitucional español.

ABSTRACT: In our technologically advanced society, with dense populations and ever greater standards of quality of life, noise is an increasing problem, to which jurisprudence, both administrative contentious, and civil and criminal, has had to respond, along the lines established by the European Court of Human Rights and the Spanish Constitutional Court.

Paraules clau: Soroll - Contaminació acústica - Drets fonamentals - Jurisdicció contenciosa administrativa - Jurisdicció civil — Jurisdicció penal. 
Palabras clave: Ruido — Contaminación acústica — Derechos fundamentales — Jurisdicción contencioso-administrativa - Jurisdicción civil — Jurisdicción penal

\author{
Keywords: Noise — Noise pollution — Fundamental rights — Administrative \\ contentious jurisdiction - Civil jurisdiction - Criminal jurisdiction.
}

Sumari: I. Introducció. 1. La jurisprudència del Tribunal Europeu de Drets Humans. 2. La jurisprudència del Tribunal Constitucional. II. La protecció en l'àmbit administratiu. 1. La tutela judicial en l'ordre contenciós administratiu. 2. La normativa administrativa. 3. Breu referència a un supòsit concret: el soroll derivat de l'activitat aeroportuària. 4. Referència a un altre supòsit concret: la celebració de festes locals. III. La protecció en l'àmbit civil. IV. La protecció en làmbit penal. V. Conclusions. VI. Bibliografia.

\title{
I. INTRODUCCIÓ
}

És prou conegut l'impacte que pot arribar a tenir el soroll sobre la salut física i psíquica de les persones ${ }^{1}$, i la preocupant dimensió que ha arribat a adquirir aquest problema en les nostres societats tecnològicament desenvolupades ${ }^{2}$, però tampoc es poden obviar

\footnotetext{
${ }^{1}$ Els efectes del soroll sobre la salut inclouen des del trauma acústic agut, amb trencament del timpà per l'impacte d'un soroll molt intens de curta durada, fins al trauma acústic crònic, amb la destrucció de les cèl-lules receptores del so i la corresponent perduda d'audició. També s'han documentat l'augment del ritme cardíac i respiratori, de l'angoixa, de l'agressivitat i del cansament; la reducció de l'activitat cerebral i, per tant, del rendiment; la reducció de l'activitat digestiva, o importants pertorbacions del son (en aquest sentit, Oficina Univerde. Guía ruido. Recuperat el 5 de maig de 2015 de $<$ http://univerde.consorciouniverde.org/guia-ruido/>).
}

S'assenyala també que el soroll pot arribar a ser la causa de neurosis ansiodepressives reactives secundàries (exògenes), distonies neurovegetatives (fins $\mathrm{i}$ tot cròniques), $\mathrm{i}$ d'un ampli ventall de patologies psíquiques, i pot agreujar problemes cardiovasculars, processos cancerígens o de colesterol, o afeccions gàstriques de tipus nerviós. Abogados contra el ruido. (2012). El ruido y la literatura. Recuperat el 5 de maig de 2015 de <http://abogadoruido.es/?p=318>.

L'Organització Mundial de la Salut assenyala que Espanya és el segon país del món amb nivells més grans de contaminació acústica, només pel darrere del Japó, i quasi 9 milions de persones pateixen nivells mitjans superiors als 65 decibels. També s'afegeix que el $55 \%$ de la població ja no hi sent igual que fa deu anys. Lavozdigital.es. (2009, 19 d'agost). Las obras y el despertador irritan a los españoles. Recuperat el 5 de maig de 2015 de <http://www.lavozdigital.es/cadiz/20090819/sociedad/obras-despertador-irritanespanoles-20090819.html>.

En aquest sentit, cal assenyalar que el cant d'un ocell és d'uns 10 decibels; una conversació animada arriba als 50; nivells entre 70 i 125 decibels poden produir dolor, i de 140 ja esdevenen dolorosament insuportables.

${ }^{2}$ Els ecobaròmetres autonòmics reflecteixen reiteradament com els ciutadans consideren, entre els problemes ambientals, el soroll com un dels que generen més preocupació. De fet, un $72,3 \%$ de la població afirma que viu en una ciutat sorollosa i el $91 \%$ que la societat no està conscienciada de la problemàtica del soroll. Infosalus.com. (2014, 30 d'abril). El 72\% de los españoles cree que vive en una ciudad ruidosa y el $91 \%$ considera que la sociedad no está conscienciada. Estudio 'GAES-Ruido y audición en España'. Recuperat el 5 de maig de 2015 de <http://www.infosalus.com/saludinvestigacion/noticia-72-espanoles-cree-vive-ciudad-ruidosa-91-considera-sociedad-no-concienciada20140430165627.html>. 
certs excessos en la lluita contra el soroll ${ }^{3}$. Activitats industrials o d'una altra mena $s$ 'han vist engolides pel creixement dels nuclis urbans, $i$, en conseqüència, han generat problemes de soroll que poden acabar suposant la seva expulsió del territori.

En aquest article analitzarem com s'ha afrontat aquest problema des de la jurisprudència contenciosa administrativa, civil i penal ${ }^{4}$. Prèviament farem una breu i obligada referència a la jurisprudència del Tribunal Europeu de Drets Humans i a la jurisprudència del Tribunal Constitucional, que inspiren la nostra jurisprudència ordinària, $\mathrm{i}$ a les quals aquesta intenta seguir amb més o menys encert.

\section{La jurisprudència del Tribunal Europeu de Drets Humans}

Tot i que el Conveni europeu per a la protecció dels drets humans i de les llibertats fonamentals de 1950 no protegeix explícitament el medi ambient com a tal, el Tribunal Europeu de Drets Humans (la jurisprudència del qual presenta una indubtable transcendència en l'ordenament intern, atès el que disposa l'article 10.2 de la Constitució) ha establert, reiteradament ${ }^{5}$, que determinats danys ambientals, tot i que no posin en perill la salut de les persones, poden atemptar contra el seu dret al respecte a la vida privada i familiar, i privar-les del gaudiment del seu domicili amb ingerències o vulneracions immaterials, com les derivades del soroll ${ }^{6}$.

Se sol fixar el percentatge d'habitatges amb problemes de soroll en l'àmbit estatal en un 40\% (Oficina Univerde. Guía ruido. Recuperat el 5 de maig de 2015 de $<$ http://univerde.consorciouniverde.org/guiaruido/>).

${ }^{3}$ Com el cas de ramaders que s'han vist obligats a silenciar les esquelles dels animals per evitar molestar veïns, procedents de les ciutats i propietaris de segones residències. NacióRipollès. Naciódigital. (2009, 15 de gener). Un ramader de Llanars precinta les esquelles de les eugues per les queixes "d'urbanites".

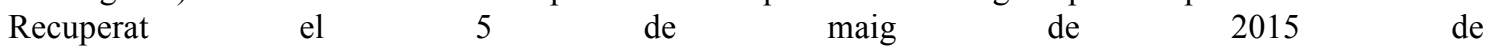
$<$ http://www.naciodigital.cat/elripolles/noticia/7437/ramader/llanars/precinta/esquelles/eugues/queixes/ur banites $>$.

${ }^{4}$ Deixant de banda l'ordre social, el qual, per les seves especificitats, excedeix dels objectius d'aquest article.

${ }^{5}$ En aquest sentit, entre d'altres, les sentències de 9 de desembre de 1994, assumpte López Ostra contra Espanya, de 26 d'agost de 1997 (Balmer-Schafroth i altres contra la Confederació Helvètica), de 19 de febrer de 1998 (Guerra i altres contra Itàlia), de 22 de maig de 2003 (Kyrtatos contra Grècia), de 20 d'abril de 2004 (assumpte Surugiu), de 6 de setembre de 2005 (Rouano Moercuende contra Espanya), de 2 de novembre de 2006 (Giacomelli contra Itàlia), de 26 d'octubre de 2006 (Ledyayeva i altres contra Rússia) o d'1 de juliol de 2008 (Borysiewicz contra Polònia).

${ }^{6}$ Així, el Tribunal incardina la protecció contra el soroll fonamentalment en l'àmbit de la inviolabilitat domiciliària de l'article 8 del Conveni. L'apartat 1 d'aquest precepte disposa que "tota persona té dret al respecte de la seva vida privada i familiar, del seu domicili i de la seva correspondència", i l'apartat 2 afegeix que "només pot haver-hi ingerència d'una autoritat pública en l'exercici d'aquest dret en la mesura que aquesta ingerència sigui prevista per la llei i que constitueixi una mesura que, en una societat 
El Tribunal Europeu afirma reiteradament que els drets del Conveni han de ser efectius i no il $\cdot$ lusoris $^{7}$, per la qual cosa correspon als poders públics adoptar les mesures necessàries per garantir-los, de manera que la seva passivitat davant ingerències mediambientals greus que impedeixen el gaudi d'aquests drets en constitueix una violació per part de les autoritats. Per tant, la vulneració dels drets del Conveni pot derivar tant d'una actuació directa de les autoritats estatals com d'una actuació privada permesa per les autoritats estatals.

A més, l'apartat 2 de l'article 8 permet al Tribunal efectuar una ponderació dels diferents interessos en conflicte en cada cas, bàsicament, els drets de les persones afectades, d'una banda, i els interessos generals, de l'altra. A més, el Tribunal reconeix un àmbit de discrecionalitat a les autoritats estatals, atès que "pel seu directe $\mathrm{i}$ continu contacte amb les forces vitals dels seus països, estan en millor posició que el jutge internacional per a donar una opinió sobre la necessitat de la ingerència o sanció" ${ }^{8}$.

Més concretament, i ja entrant en les principals decisions del Tribunal en aquesta matèria, cal començar esmentant la Sentència de 21 de febrer de 1990, assumpte Powell i Rayner contra el Regne Unit, relatiu als sorolls procedents de l'aeroport de Heathrow. Tot i que la sentència desestimà el recurs, va admetre la possibilitat que determinats nivells de soroll, com que perjudicaven la qualitat de vida de les persones, podien privar del dret a gaudir del domicili i, en conseqüència, vulnerar l'article 8 del Conveni. Resulta interessant destacar la ponderació que efectua el Tribunal entre els interessos del individu i els del conjunt de la societat, i el reconeixement d'un marge d'apreciació

democràtica, és necessària per a la seguretat nacional, la seguretat pública, el benestar econòmic del país, la defensa de l'ordre i la prevenció de les infraccions penals, la protecció de la salut o de la moral, o la protecció dels drets i les llibertats d'altri". Certament, també s'ha invocat davant del Tribunal Europeu l'article 2 del Conveni, referent al dret a la vida, al·legant l'afectació de la salut i integritat física, o fins i tot l'article 3, que prohibeix la tortura i el tracte inhumà i degradant, però el Tribunal no ha admès aquestes al·legacions, que exigirien un problema ambiental d'una enorme intensitat. Així, per exemple, en la Sentència de 19 de febrer de 1998 (Guerra i altres contra Itàlia), el Tribunal considerà suficient la vulneració de l'article 8 i no entrà a analitzar la possible violació també de l'article 2 , tot i que, per exemple, el jutge Jambrek, en la seva opinió concordant, afirmà que "és possible que hagi arribat el moment que la jurisprudència del Tribunal evolucioni, desenvolupi els drets que se'n derivin per implicació, defineixi les situacions que impliquen un risc real i greu per a la vida o els diferents aspectes del dret a la vida".

${ }^{7}$ Sentència 16/2004, assumpte Moreno Gómez contra Espanya, entre d'altres.

${ }^{8}$ Sentència de 25 de setembre de 1996, assumpte Buckley contra el Regne Unit. MARISCAL AGUILAR, C. M. "La protección del medio ambiente en la jurisprudencia del Tribunal Europeo de Derechos Humanos a través de la consideración del derecho al medio ambiente adecuado como parte del interés general en una sociedad democrática", en Medio ambiente y derecho: revista electrónica de derecho ambiental, número 24, febrer 2013. Recuperat el 5 de maig de 2015 de $<$ http:/huespedes.cica.es/gimadus/24/05.html $>$. 
que correspon a les autoritats estatals. En aquest cas, el Tribunal constata que les autoritats havien adoptat diverses mesures per controlar el soroll, i que el funcionament de grans aeroports com el de Heathrow, prop d'àrees residencials densament poblades, és necessari per al benestar econòmic dels països, tot i que l'impacte negatiu no pugui eliminar-se completament.

En la Sentència de 9 de desembre de 1994, assumpte López Ostra contra Espanya, es plantejaren les molèsties per sorolls, gasos i olors pestilents generades per una planta de depuració d'aigües i residus a Lorca (Múrcia), propera al domicili de la demandant. En aquell cas, tot $\mathrm{i}$ que les instàncies judicials espanyoles (inclòs el Tribunal Constitucional) no apreciaren violació de drets fonamentals, el Tribunal considerà que s'havia violat l'article 8.1 del Conveni, atès que la família va haver d'afrontar les molèsties causades per la planta durant tres anys, fins que va haver de canviar de domicili, afegint que, tot i el marge d'apreciació de l'Estat, aquest no aconseguí un just equilibri entre l'interès del benestar econòmic de la ciutat $i$ el dret de la demandant al respecte a la seva vida privada i familiar i al seu domicili. El Tribunal, no aprecià, però, una violació de l'article 3.

En l'assumpte Hatton i altres contra el Regne Unit es plantejaren les molèsties derivades dels vols nocturns a l'aeroport de Heathrow. Tot i que la primera Sentència de 2 d'octubre de 2001 aprecià una violació de l'article 8 del Conveni, la Gran Sala, en la Sentència de 8 de juliol de 2003, assenyalà novament l'existència d'un interès econòmic en el manteniment d'un servei de vols nocturns, per la qual cosa no aprecià vulneració de l'article 8 del Conveni, i afegí també que el preu dels habitatges no havia baixat i que els afectats podien mudar-se a qualsevol altre lloc sense patir perjudicis econòmics.

En la Sentència de 16 de novembre de 2004, assumpte Moreno Gómez contra Espanya, el Tribunal recorda que l'article 8 del Conveni consagra el dret de l'individu al respecte a la seva vida privada i familiar i al seu domicili, que suposa, no només el dret a un espai físic, sinó també el dret a l'aprofitament tranquil d'aquest espai, i, en conseqüència, aquest dret pot ser violat, no només per entrades físiques no autoritzades, sinó també per intrusions no físiques com el soroll o les vibracions. En aquell cas, el Tribunal constata que la recurrent viu en una zona sotmesa indiscutiblement a pertorbacions sonores, la qual cosa fa innecessari exigir-li, com van fer els tribunals espanyols, proves d'aquest fet, del qual l'autoritat municipal ja n'era oficialment conscient (de fet, el seu barri, per la proliferació de bars, pubs i discoteques, havia estat 
declarat pel mateix Ajuntament zona acústicament saturada), i atesa la intensitat dels sorolls i que es produïren durant anys, el Tribunal conclou que la recurrent ha patit una greu violació del seu dret al respecte del seu domicili, com a conseqüència de la passivitat de l'Administració, la qual, si bé adoptà algunes mesures correctores, també és cert que tolerà, i d'aquesta manera, contribuí, al reiterat incompliment de les regles que ell mateix havia establert ${ }^{9}$.

Així mateix, tant en la Sentència de 29 d'abril de 2010, assumpte Oulic contra Croàcia (en el qual es plantejaren les molèsties pels sorolls d'un bar), com en la Sentència de 25 de novembre de 2010, assumpte Mileva i altres contra Bulgària (sobre els sorolls causats per una oficina, un club de jocs electrònics i un club informàtic), el Tribunal conclou que es violà l'article 8 del Conveni, atenent a l'actuació tardana de l'Administració, en el primer cas, i perquè les prohibicions dictades per l'Administració no es van fer efectives, en el segon. Per tant, ja es pot concloure que és exigible una actuació administrativa efectiva i sense retards.

Cal esmentar també la Sentència de 9 de novembre de 2010, assumpte Deés contra Hongria, en relació amb els sorolls i les vibracions causats pel trànsit pesant no reglamentat que es produïa al carrer de la part afectada. El Tribunal considera que, tot $\mathrm{i}$ els esforços de les autoritats, que van adoptar una gran diversitat de mesures d'elevat cost, i tot i el marge d'apreciació que correspon a l'Estat, s'han causat, durant un període substancial de temps, molèsties directes i sèries al particular, i, per tant, una violació del que disposa l'article 8 del Conveni. És a dir, en aquest cas, el Tribunal considera que, tot i les mesures d'elevat cost adoptades, s'ha produït una violació del Conveni, atesa la ineficàcia d'aquests mitjans, per la qual cosa sembla que tampoc seria suficient només amb una actuació administrativa real, sinó que, a més, aquesta actuació hauria de solucionar realment el problema ${ }^{10}$.

En la Sentència de 21 de juliol de 2011, assumpte Grimkovskaya contra Ucraïna, relatiu a les molèsties per soroll, vibracions i contaminació derivades de la construcció d'una autopista, el Tribunal assenyala que, si bé no es pot exigir a l'Estat l'obligació

\footnotetext{
9 El Tribunal afirma que "una reglamentació per a la protecció de drets garantits seria una mesura il·lusòria si no és observada de manera constant, i el Tribunal ha de recordar que el Conveni vol protegir els drets efectivament i no de manera il·lusòria o teòrica".

${ }^{10}$ Un estudi d'aquesta sentència es pot trobar a APODACA ESPINOSA, A.R. "La tutela del TEDH frente a la contaminación acústica continúa y se acentúa (comentario a la STEDH Deés C. Hungría, de 9 de noviembre de 2010)", en Revista Jurídica de Navarra, n. 50, juliol-desembre 2010, pp. 211-228.
} 
d'assegurar a tot preu i per a tota persona el gaudi del seu domicili d'acord amb la normativa ambiental aplicable, ha d'establir-se un equilibri ponderat entre els interessos generals i els de les parts demandants, i, en aquest cas, l'Administració no ha tingut en compte les implicacions de la construcció de l'autopista (no es van elaborar els estudis ambientals sobre l'impacte de l'obra), ni s'han fixat fórmules de participació dels damnificats en les decisions que els afectarien, ni se'ls ha permès recórrer judicialment. Per tant, el Tribunal conclou amb l'existència d'una vulneració de l'article 8 del Conveni. Sembla, doncs, com afirma NOEMÍ GARCÍA GESTOSO ${ }^{11}$, que es dilueix l'exigència d'un resultat satisfactori en les mesures adoptades i se substitueix per una exigència de prevenció i possibilitat de participació en les decisions ambientals.

En la Sentència de 22 de novembre de 2011, assumpte Zammit Maempel contra Malta, relativa als sorolls causats per focs artificials durant festes locals, el Tribunal afirma que, tot i tractar-se d'una contaminació acústica purament ocasional i no continuada, els sorolls eren suficientment greus per poder vulnerar l'article 8 del Conveni —obrint així la porta a admetre una conculcació del Conveni també en supòsits de contaminació acústica ocasional-, però també afirma que les parts reclamants no provaren l'existència de greus riscos per a les seves persones o propietat, i, després de recordar la necessitat de ponderar els interessos en conflicte i el marge d'apreciació de les autoritats, considera que, en aquest cas, no hi havia altres llocs alternatius per als focs artificials, i en conseqüència, conclou que no es vulnerà l'article 8 del Conveni.

En la Sentència de 4 d'octubre de 2011, assumpte Orlikowsky contra Polònia, es plantejà la construcció il·legal d'una carnisseria i posterior ampliació d'una planta de fumat que generaven molèsties per sorolls. El Tribunal considera que el simple fet que l'obra fos il·legal no és suficient per acollir les al·legacions de les parts demandants, ja que cal acreditar que les molèsties per sorolls han arribat a un nivell mínim de gravetat, cosa que, en aquest cas, les parts demandants no van fer.

Quant a la Sentència de 18 d'octubre de 2011, assumpte Martínez Martínez contra Espanya, en aquell cas es tractava del soroll nocturn d'una discoteca amb una terrassa molt propera al domicili de la part demandant. El Tribunal reitera que el dret al domicili implica el dret a gaudir amb tranquil-litat d'aquest espai físic, i que l'Estat està obligat a adoptar les mesures raonables i oportunes per protegir els drets de les persones, i, en

11 GARCía GESTOSO, N.,"Contaminación acústica y derechos fundamentales. Protección y discrepancias en su tutela judicial”, en Foro, Nueva época, vol. 15, núm.1, 2012, pp. 109-134. 
aquest cas, constata que s'ha superat el llindar de soroll permès — sense exigir tampoc l'acreditació dels nivells de soroll a l'interior de l'habitatge-, que existeix una relació de causalitat entre el soroll i els danys i que l'Administració no ha adoptat cap mesura per solucionar el problema, per la qual cosa aprecia una violació de l'article 8 del Conveni. El Tribunal no entra en l'al·legació del Govern espanyol relativa a la il·legalitat de la construcció de l'habitatge de la part demandant, atès que aquest no aportà cap element per demostrar-ho ${ }^{12}$.

En la Sentència de 3 de juliol de 2012, assumpte Martínez Martínez i Pino Manzano contra Espanya, es plantejaren les molèsties per pols i soroll d'una pedrera sobre un habitatge construït sense autorització en sòl rústic. El Tribunal, a banda de constatar que la pertorbació no arriba al nivell mínim de gravetat ${ }^{13}$, considera que el fet que l'habitatge se situï en una zona no residencial suposa que les parts demandants s'han situat fora de la legalitat $i$, per tant, n'han d'assumir les conseqüències ${ }^{14}$.

Pel que fa a la Sentència de 13 de desembre de 2012, assumpte Flamenbaum i altres contra França, derivat dels sorolls causats per l'ampliació de la pista principal d'aterratge de l'aeroport de Deauville-Saint Gatien, el Tribunal reconeix que les parts reclamants havien estat sotmeses a uns nivells de soroll prou greus, però també assenyala que la ingerència estava prevista en el dret intern, perseguia un objectiu legítim (el benestar econòmic de la regió), s’havia aconseguit un just equilibri entre els interessos contraposats per les mesures adoptades i s'havia permès a les parts reclamants participar i efectuar observacions al projecte, per la qual cosa no aprecia vulneració del Conveni.

\footnotetext{
12 Estudia aquesta sentència GARCÍA URETA, A. "El ruido ante el Tribunal Europeo de Derechos Humanos. Otra llamada de atención a la jurisdicción contencioso-administrativa (y también al Tribunal Constitucional): Comentario a Martínez Martínez v. España, sentencia del TEDH de 18 de octubre de 2011", en Actualidad Jurídica Ambiental, núm. 7, novembre 2011, pp- 1 a 12. Recuperat el 5 de maig de $2015 \mathrm{de} \mathrm{http} / / \mathrm{www}$.actualidadjuridicaambiental.com/comentario-el-ruido-ante-el-tribunal-europeo-dederechos-humanos-otra-llamada-de-atencion-a-la-jurisdiccion-contencioso-administrativa-y-tambien-altribunal-constitucional-comentario-a-martinez/

${ }^{13}$ Tampoc falten altres supòsits en els quals el Tribunal ha considerat que no es vulnerava el Conveni perquè les inmissions no arribaven a un mínim de gravetat, juntament amb els interessos públics presents en l'activitat que les generava (així, per exemple, Decisió de 6 de setembre de 2005, María Isabel Ruano Morcuende contra Espanya).

${ }^{14}$ En aquest mateix assumpte, el Tribunal Superior de Justícia de València, mitjançant la Sentència de 7 d'abril de 2006, desestimà el recurs de les parts demandants considerant també que s'havien col·locat, per la seva pròpia voluntat, en la situació d'haver de suportar les probables immissions procedents de la pedrera.
} 
En la Sentència de 18 de juny de 2013, assumpte Bor contra Hongria, relativa al soroll causat per una estació ferroviària propera a l'habitatge de la part demandant que superava els nivells establerts per la legislació vigent, el Tribunal considera que, tot $\mathrm{i}$ tractar-se d'una important infraestructura de transport, i malgrat que es van adoptar mesures pal·liatives, a causa de l'important retard d'aquests accions (uns disset anys), es va vulnerar l'article 8 del Conveni. Per tant, el retard en l'actuació de l'Administració esdevé també un element important a l'hora de determinar si s'ha assolit un just equilibri entre els interessos particulars i públics.

\section{La jurisprudència del Tribunal Constitucional espanyol}

L'article 45 de la Constitució proclama el dret a un medi ambient adequat, amb una referència expressa a la finalitat de protecció i millora de la qualitat de vida, però, tot $\mathrm{i}$ que, d'acord amb l'article 53 de la Constitució, la legislació positiva, la pràctica judicial i l'actuació dels poders públics s'ha d'orientar al seu respecte i protecció, aquest precepte, com a principi rector de la política social i econòmica, requereix desplegament legislatiu i no permet un recurs d'emparament basat exclusivament en la seva violació. Per aquesta raó, i també i molt principalment per la jurisprudència del Tribunal Europeu de Drets Humans, el Tribunal Constitucional ha acabat entenent que el soroll pot arribar afectar drets de primera generació, com els drets fonamentals a la vida i a la integritat física i moral (article 15) o a la intimitat personal i familiar i la inviolabilitat del domicili (article 18, apartats 1 i 2), aquests drets, sí, susceptibles de tutela a través del procediment preferent $\mathrm{i}$ sumari davant la jurisdicció ordinària i mitjançant el recurs d'empara davant del Tribunal Constitucional (article 53.2) ${ }^{15}$.

\footnotetext{
${ }^{15}$ ANDRÉS ALONSO, F.L., "La jurisprudència constitucional y contencioso-administrativa en materia de contaminación acústica", en Revista Xurídica Galega, núm. 40, 2003 , pp. 61-92.

Cal no oblidar també altres referències constitucionals que poden resultar aplicables al problema de la contaminació acústica, com el mateix preàmbul (que es refereix als "drets humans" i a una "digna qualitat de vida"), l'article 10.1 (que proclama la dignitat de la persona i el lliure desenvolupament de la seva personalitat), l'article 43 (que reconeix el dret a la protecció de la salut) o l'article 47 (que proclama el dret a un habitatge digne i adequat). També els estatuts d'autonomia de nova generació incorporen referències que cal tenir en compte. Així, per exemple, l'Estatut d'autonomia de Catalunya estableix, en el capítol I (dedicat als “Drets i deures de l'àmbit civil i social”), a l'article 27, els drets a viure en un medi ambient equilibrat, sostenible i respectuós amb la salut i a la protecció davant les diferents formes de contaminació, d'acord amb els estàndards i els nivells de protecció que determinen les lleis, i el deure de col-laborar en les actuacions que tendeixin a eliminar les diferents formes de contaminació. Al capítol V ("Principis rectors"), l'article 46 afegeix el manament als poders públics de vetllar per la protecció del medi ambient per mitjà de l'adopció de polítiques públiques basades en el desenvolupament sostenible $\mathrm{i}$ la solidaritat col·lectiva i intergeneracional, i afegeix que les polítiques mediambientals s'han de dirigir
} 
Les sentències del Tribunal Constitucional 119/2001, de 24 de maig; 16/2004, de 23 de febrer; 25/2004, de 26 de febrer, i 150/2011, de 29 de setembre, modifiquen la jurisprudència anterior del mateix Tribunal (que no considerava aplicables els drets dels articles 15 i 18 als supòsits de contaminació acústica), i invoquen expressament l'esmentada jurisprudència del Tribunal Europeu de Drets Humans (de conformitat amb l'article 10.2 de la Constitució), entenent que la Constitució no proclama drets teòrics, sinó reals i efectius, per la qual cosa cal garantir la seva protecció, no només davant les ingerències de terceres persones, sinó també dels riscos que poden sorgir en una societat tecnològicament avançada.

El Tribunal Constitucional assenyala que el soroll pot arribar a constituir un factor psicopatogen destacat en aquesta societat i una font permanent de pertorbació de la qualitat de vida dels ciutadans (com acrediten les directrius de l'Organització Mundial de la Salut, que posen de manifest les conseqüències d'una exposició prolongada al soroll, tant sobre la salut — deficiències auditives, aparició de dificultats de comprensió oral, pertorbació del son, neurosis, hipertensió, isquèmia - com sobre la conducta social —reducció de comportaments solidaris i augment de les tendències agressives). En conseqüència, el Tribunal afirma que una exposició intensa i prolongada al soroll pot arribar a afectar el dret a la integritat física i moral de l'article 15.1 CE, sempre que suposi un perill greu i immediat per a la salut, i que quan el soroll no és tan intens, pot afectar el dret a la intimitat personal i familiar en l'àmbit domiciliari de l'article $18 \mathrm{CE}$, en la mesura que impedeix el lliure desenvolupament de la personalitat, sempre que aquesta afectació provingui d'accions o omissions d'ens públics als que sigui imputable ${ }^{16}$.

especialment a la reducció de les diferents formes de contaminació, la fixació d'estàndards i nivells mínims de protecció, l'articulació de mesures correctives de l'impacte ambiental, i el respecte als principis de preservació del medi o responsabilitat, entre d'altres.

\footnotetext{
${ }^{16}$ En aquest sentit, fonament jurídic sisè de la Sentència 119/2001. Seguint el magistrat Jiménez de Parga, en el seu vot particular en la Sentència del Tribunal Constitucional 119/2001, caldria distingir un triple nivell de protecció constitucional que, en sentit descendent, abastaria el dret fonamental a la integritat física i moral, el dret fonamental a la intimitat domiciliària i el dret a un medi ambient adequat. Quant al dret a la integritat física i moral, l'esmentat magistrat rebutja, en línia amb la legislació europea, la separació que l'esmentada sentència efectua entre aquest dret i el de la salut de l'article 43, entenent, en contra de la resta del Tribunal, que la vulneració de l'article 15 de la Constitució no exigeix un perill greu i immediat per a la salut de les persones, i és suficient qualsevol efecte nociu. Resulta també interessant destacar aquest vot particular perquè assenyala que la protecció contra el soroll s'ha d'establir tant dins com fora del domicili . Efectivament, en atorgar un paper fonamental en aquesta matèria al dret a la intimitat domiciliaria, s'estan bandejant tots aquells àmbits de la vida de les persones que es desenvolupen fora de l'estricte recinte domiciliari, els quals, en una societat mediterrània com la nostra, tenen una transcendència que no es pot menystenir.
} 
Els requisits que exigeix el Tribunal Constitucional per considerar vulnerat l'article 18.1 i 18.2 de la Constitució es podrien sintetitzar així: 1) existència de nivells de soroll insuportables que impedeixin o dificultin greument el lliure desenvolupament de la personalitat; 2) exposició prolongada a aquests nivells de soroll; i 3 ) que aquesta exposició sigui objectivament evitable, i que derivi d'una acció o omissió dels poders públics. Novament, i com ja hem vist amb la jurisprudència del Tribunal Europeu de Drets Humans, s'estableixen obligacions positives per als poders públics davant de la vulneració de drets procedents de particulars, entenent que la ingerència il·lícita per soroll produït per particulars és imputable al poder públic que incorre en omissió en la tutela del dret afectat ${ }^{17}$.

En definitiva, el Tribunal Constitucional ha reconegut l'aplicabilitat de drets fonamentals, drets clàssics de primera generació que gaudeixen d'un màxim nivell de protecció constitucional, en la defensa contra agressions ambientals d'especial gravetat, fet que no deixa de ser una conseqüència, en definitiva, de la dèbil protecció que l'ordenament jurídic atorga al medi ambient. Tanmateix, aquesta protecció davant del soroll recorrent a l'aplicació de drets fonamentals no és pacífica, ni entre els mateixos magistrats del Tribunal Constitucional ${ }^{18}$, ni en la doctrina, en la qual no falten veus que assenyalen les perilloses conseqüències que es poden derivar d'aquesta concepció ${ }^{19}$.

\footnotetext{
${ }^{17}$ En aquest sentit, el magistrat Garrido Falla, en el seu vot particular concordant a la Sentència de 119/2001, de 29 de maig, relativa a un l'assumpte que posteriorment fou objecte de la Sentència del Tribunal Europeu de Drets Humans en l'assumpte Moreno Gómez, a la qual ja s'ha fet referència, entén que per a un ajuntament és obligatori, en exercici de les seves potestats, impedir actuacions subjectes a llicència quan d'aquestes activitats se'n deriva una lesió greu de drets fonamentals.
}

${ }^{18}$ Així, per exemple, en el vot particular concurrent del magistrat Manuel Aragón Reyes a la STC 150/2011, de 29 de setembre, s'assenyala que l'article 10.2 de la Constitució no permet ampliar el llistat de drets fonamentals (a diferència del que passa a la Constitució portuguesa), sinó que només n'imposa una interpretació d'acord amb els tractats internacionals, i que l'article 18 de la Constitució no inclou un "dret al silenci" (el qual existirà com a dret subjectiu aplicable pels tribunals ordinaris ex article 96.1 a partir de l'article 8.1 del Conveni, però no com a dret fonamental). Aquest magistrat considera, doncs, que ens trobem davant una incorporació encuberta de nous drets fonamentals.

${ }^{19}$ Així, CASINO RUBIO, M., "La responsabilidad civil como forma inesperada de tutela de los derechos fundamentales (más sobre el ruido y su control constitucional)", en Revista Española de Derecho Constitucional, núm. 102, 2014 , pp. 353-386. Aquest autor considera que ens trobem davant d'un problema de responsabilitat patrimonial de l'Administració i, per tant, de legalitat ordinària, ja que la funció de la responsabilitat civil extracontractual no és restablir un dret subjectiu vulnerat, sinó simplement indemnitzar el dany causat. Aquesta naturalesa no canvia pel mer fet que s'invoquin en la demanda els drets fonamentals dels articles 15 o 18 de la Constitució. En cas contrari, no només els supòsits de soroll, sinó el gruix de supòsits de responsabilitat patrimonial administrativa per mort o lesions acabarien tenint accés al recurs d'emparament per la via de l'article 15 de la Constitució, en una mena d'expansió descontrolada i sense límits clars dels drets fonamentals. Aquest autor també sosté que el soroll, en casos molt greus, pot arribar a afectar, en tot cas, el dret de l'article 15, però no la intimitat 0 la inviolabilitat del domicili en els termes de l'article 18 de la Constitució, considerant encara més criticable el fet que aquesta vulneració de l'article 18 sigui imputable a l'Administració, que ni tan sols ha 
D'altra banda, la doctrina no ha deixat d'assenyalar discrepàncies entre el Tribunal Constitucional i el Tribunal Europeu de Drets Humans en els requisits i procediment necessaris per acreditar el soroll, $\mathrm{i}$ ha contraposat l'antiformalisme general del Tribunal Europeu amb el formalisme propi del Tribunal Constitucional ${ }^{20}$. En aquest sentit, la Sentència del Tribunal Constitucional 150/2011, de 29 de setembre, desestimà l'emparament sol-licitat per una persona que vivia en el mateix barri que la senyora Moreno Gómez, entenent que no s'acredità amb cap mitjà de prova l'existència, el nivell i la repercussió del soroll en l'interior de l'habitatge, ja que només es van provar els nivells de soroll extern (en contrast amb la posició del Tribunal Europeu), i perquè cal provar que el menyscapte en la salut o en la intimitat és imputable a l'acció o omissió d'un poder públic, i assenyala que, després de la Sentència del Tribunal Europeu de Drets Humans en l'assumpte Moreno Gómez, l'Ajuntament ha desplegat una intensa activitat contra el soroll a la zona, amb nombrosos expedients i sancions.

És a dir, com encertadament assenyala NOEMÍ GARCÍA GESTOSO ${ }^{21}$, sembla que s'entén que si hi ha una actuació del poder públic, ja no hi hauria responsabilitat d'aquest poder públic, encara que l'actuació esdevingui ineficaç (FJ 9è), i s'estableix una mera obligació d'actuar però no necessàriament d'obtenir un resultat satisfactori que solucioni el problema (en contradicció, per exemple, amb la posició del Tribunal Europeu en la Sentència de 20 d'octubre de 2010, assumpte Deés contra Hongria), segurament per evitar una allau de reclamacions de responsabilitat patrimonial per part de tots els que viuen en zones qualificades per la mateixa Administració com a saturades acústicament ${ }^{22}$.

generat el soroll. Això acaba convertint aquests drets, tradicionalment de llibertat, en drets de caràcter prestacional, que obliguen els poders públics a adoptar mesures positives i, per tant, de configuració legal, i a més suposaria la competència exclusiva del legislador orgànic estatal en aquesta matèria, ex. article 81 CE. No obstant això, el Tribunal Constitucional tampoc es fixa en l'actuació del legislador, sinó només en la de l'Administració, que és responsable o no segons el nombre d'expedients i sancions imposades. Per tant, es pot acabar produint precisament l'efecte contrari al desitjat, desincentivant la intervenció administrativa, ja que és impossible controlar tots els incompliments possibles, i al final l'Administració no tindrà cap interès a aprovar ordenances i reglamentacions contra el soroll que poden acabar girant-se en contra seva i de les seves finances.

${ }^{20}$ En aquest sentit, PÉREZ SOLA, N., "El ruido y la integridad real y efectiva de los derechos fundamentales (reflexiones a propósito de la jurisprudencia del Tribunal Europeo de Derechos Humanos y el Tribunal Constitucional)", Revista Española de Derecho Administrativo, núm. 156, 2012, pp. 173200.

${ }^{21}$ En l'article ja esmentat a la nota 10 .

${ }^{22}$ En aquest sentit, cal fer referència al vot particular discrepant del magistrat Ortega Álvarez, al qual s'adheriren els magistrats Eugeni Gay Montalvo i Elisa Pérez Vera, que assenyalaren que en aquell cas hi havia proves objectives proporcionades per la mateixa autoritat pública de la superació dels límits legals 
Arribats a aquest punt, ja podem començar el nostre recorregut per les jurisdiccions ordinàries, recordant, com a punt de partida, que el mateix article 45 de la Constitució disposa que per als qui atemptin contra el medi ambient, s'han d'establir sancions penals o administratives, així com l'obligació de reparar el dany causat. D'aquesta manera, es reconeix ja des del punt de vista constitucional, la triple protecció contra el soroll: penal, administrativa i civil ${ }^{23}$.

\section{LA PROTECCIÓ EN L’ÀMBIT ADMINISTRATIU}

\section{La tutela judicial en l'ordre contenciós administratiu}

El reconeixement jurisprudencial de la responsabilitat patrimonial de les administracions en supòsits d'inactivitat davant la contaminació acústica derivada tant d'activitats públiques com privades, ha convertit aquesta via en el principal instrument de reacció dels particulars contra el soroll. Així, el ciutadà ha d'acudir, en primer lloc, al procediment administratiu, i formular les sol-licituds, queixes i reclamacions pertinents perquè l'Ajuntament exerciti les seves competències de policia ambiental a fi de solucionar el problema. En cas que l'Administració municipal no atengui les seves peticions, i un cop esgotada la via administrativa, pot acudir als tribunals contenciosos administratius i sol·licitar una indemnització i la condemna de l'administració a actuar.

I és que la Constitució, a l'article 106.2, reconeix als particulars, en els termes establerts per les lleis, el dret a ser indemnitzats per tota lesió que pateixin en els seus béns i drets, tret dels casos de força major, sempre que aquesta lesió sigui conseqüència del funcionament dels serveis públics ${ }^{24}$. Es tracta d'una responsabilitat objectiva, per la qual

de soroll en la zona del domicili de la part recurrent, per la qual cosa aquest no hauria d'estar obligat a aportar a més una prova individualitzada del nivell de soroll en l'interior del seu habitatge, i afegiren que caldria analitzar si l'activitat de l'autoritat pública ha estat suficient, cosa que no s'ha fet per por d'obrir la porta a una multitud de reclamacions.

${ }^{23}$ Així s'expressa la Sentència del Tribunal Suprem, Sala Segona, de 24 de febrer de 2003.

${ }^{24}$ Els articles 139 i següents de la Llei 30/1992, de 26 de novembre, de règim jurídic de les administracions públiques i del procediment administratiu comú, despleguen aquest precepte, $\mathrm{i}$ reconeixen el dret dels particulars a ser indemnitzats per les administracions sempre que la lesió sigui conseqüència del funcionament normal o anormal dels serveis públics i es tracti de danys que el particular no tingui el deure jurídic de suportar d'acord amb la Llei. El dany, naturalment, haurà de ser efectiu, avaluable econòmicament i individualitzat en relació amb una persona o grup de persones (art. 139.2). Mitjançant el Reial decret 429/1993, de 26 de març, s'aprovà el Reglament dels procediments de les administracions públiques pel que fa a responsabilitat patrimonial. Cal tenir en compte que, a la data de finalització d'aquest article, s'han publicat la Llei 39/2015, d'1 d'octubre, del procediment administratiu comú de les administracions públiques (que deroga la Llei 30/1992 i el Reial decret 429/1993) i la Lei 40/2015, d'1 d'octubre, del règim jurídic del sector públic, les dues amb una vacatio legis d'un any (pel 
cosa no cal demostrar que els titulars o gestors de l'activitat administrativa han actuat amb dol o culpa, ni tan sols que el servei públic ha funcionat de manera anòmala ${ }^{25}, \mathrm{i}$ directa, en relació de causa efecte, sense intervencions estranyes que alterin el nexe causal, segons reiterada jurisprudència ${ }^{26}$. Perquè el dany sigui antijurídic, n'hi ha prou que el risc hagi superat els límits imposats pels estàndards de seguretat exigibles conforme a la consciència social, sense existir en aquest cas l'obligació de la part perjudicada de suportar el dany ${ }^{27}$.

Certament, en molts casos hi ha hagut una deixadesa de l'Administració local, que ha permès activitats altament sorolloses (discoteques, terrasses, botellón, indústries, etc.), i, en conseqüència, els tribunals contenciosos han condemnat reiteradament els ajuntaments per inactivitat en l'exercici de les seves competències pel que fa a policia ambiental $^{28}$.

En aquest sentit, es pot esmentar la Sentència del Tribunal Superior de Justícia de Navarra de 10 de desembre de 2004 (Secció 1a, n. 1216/2004, rec. 276/2003, ponent Ignacio Merino Zalba), segons la qual "Primero, hay un deber general de la Administración de inspección y policía. Segundo, ese deber es especial cuando se trata de la seguridad de los ciudadanos. Tercero, [...] aunque no es exigible a la Administración que se entere de todo nada más ocurrir, determinados sucesos son «previsibles y evitables con una adecuada inspección». Cuatro, ad cautelam la jurisprudencia se ve obligada a precisar que la Administración «siempre podrá repetir contra quien aparezca como causante [...] de la quiebra del servicio público»”.

que fa a responsabilitat patrimonial, caldrà tenir en compte, entre d'altres, els articles 65, 67, 81 91, 92 de la Llei 30/2015, i el capítol IV de la Llei 40/2015). L'article 54 de la Llei 7/1985, de 2 d'abril, reguladora de les bases de règim local, també disposa la responsabilitat directa de les entitats locals pels danys $i$ perjudicis causats als particulars en els seus béns i drets com a conseqüència del funcionament dels serveis públics o l'actuació de les seves autoritats, funcionaris o agents en els termes establerts en la legislació general sobre responsabilitat administrativa. També cal esmentar el títol VI de la Llei 26/2010, de 3 d'agost, de règim jurídic i de procediment de les administracions públiques de Catalunya.

${ }^{25}$ Sentència del Tribunal Suprem de 28 de novembre de 1998 i posteriors.

26 Sentència del Tribunal Suprem d'11 de febrer de 1991, i altres posteriors. Una altra línia jurisprudencial no exigeix exclusivitat en el nexe causal, i modera la responsabilitat de l'Administració quan concorren altres causes del dany.

${ }^{27}$ Entre d'altres, i pel que fa al soroll, la Sentència del Tribunal Superior de Justícia de Catalunya de 8 de maig de 2013 (Secció 4a, n. 549/2013, rec. 142/2012, ponent Eduardo Barrachina Juan).

${ }^{28}$ Per exemple, entre moltes, les sentències del Tribunal Suprem de 12 de novembre de 2007 (Secció 7a, rec. 255/2014, ponent Eduardo Calvo Rojas) o de 2 de juny de 2008, més endavant esmentada. 
La jurisprudència contenciosa es mostra especialment atenta a l'efectivitat real dels drets fonamentals, efectuant, com veiem en la jurisprudència del Tribunal Europeu de Drets Humans, una ponderació entre aquests drets i els altres interessos col·lectius implicats, però, tanmateix, i com veurem també en altres jurisdiccions, un dels principals problemes que es plantegen en aquesta matèria és la prova del nexe de causalitat entre el soroll i els danys.

Així, per exemple, la Sentència del Tribunal Superior de Múrcia de 28 d'octubre de 2013 (Secció 2a, n. 827/2013, rec. 128/2013, ponent Abel Ángel Sáez Doménech) efectua aquesta ponderació entre drets fonamentals de la part particular afectada i interessos generals, entenent que el fet que la part actora hagi de suportar els sorolls procedents d'altres focus perquè el seu habitatge es troba en una zona comercial i turística, acústicament contaminada, no implica que també hagi de suportar el soroll del servei de recollida d'escombraries, quan és viable col·locar els contenidors a un altre $1 \operatorname{loc}^{29}$. La sentència, però, no considera acreditats els danys, ni el nexe de causalitat, atès que existeixen altres focus de soroll que afecten la part apel·lant ${ }^{30}$.

\footnotetext{
${ }^{29}$ La sentència afirma que "Lo anterior determina la procedencia de estimar el recurso en este punto, dando prioridad a los referidos derechos fundamentales sobre cualesquiera otros que pueda haber tenido en cuenta el Ayuntamiento, como por ejemplo los de tipo económico o de ahorro [...] Resulta al respecto ilustrativa la STS de 26-11-2007 en un supuesto de ruidos por la limpieza municipal, que señala que la solución más económica no solo es posible sino aconsejable, pero no puede ser prioritaria sobre el derecho al descanso, a la inviolabilidad del domicilio y a la intimidad personal y familiar que son derechos fundamentales reconocidos en la Constitución", per la qual cosa la sentència estima el recurs, si bé deixant llibertat a l'Ajuntament per escollir el punt on s'han d'ubicar els contenidors i la ruta que ha de seguir el camió de recollida. El que no admet la sentència és la modificació de l'horari de les màquines escombradores, "al haber quedado demostrado por la prueba practicada que necesariamente deben hacerlo a primera hora de la mañana para la limpieza de los Centros Comerciales y sus aledaños cuando no hay tráfico de vehículos de carga o descarga de proveedores o de clientes o público en general”. També pel que fa als serveis de neteja, es pot esmentar la Sentència del Tribunal Suprem de 26 de novembre de 2007 (Secció 7a, rec. 1204/2004, ponent José Díaz Delgado), que confirmà la Sentència del Tribunal Superior de Justícia del País Basc que va anul·lar la resolució municipal denegatòria de la petició d'indemnització dels danys i perjudicis derivats del soroll suportat per les labors de neteja municipal en horari nocturn, que ordenà el cessament d'aquesta activitat $\mathrm{i}$ una indemnització de deu mil euros. La Sala considera que la persistència durant dos anys dels sorolls periòdics generats pel servei públic de neteja pot produir un estat de crispació, que altera psíquicament, amb òbvies repercussions físiques, i ocasiona la impossibilitat del gaudi del domicili.

${ }^{30}$ Afirma que "Teniendo en cuenta que está acreditado que en la zona existen otros focos de ruido además del procedente de los camiones de recogida de basura, los cuales pueden ser incluso más intensos y molestos (procedentes de los locales de copas, supermercados etc.) [...] Ello determina que de existir los daños a la salud que alega, no existe una prueba irrefutable que demuestre que provengan de los ruidos procedentes de los camiones de recogida de basura y no de los otros focos de ruido existentes en la zona, ni tampoco en que porcentaje obedecen a unos u a otros". També es pot citar la Sentència del Tribunal Superior de Justícia de València de 30 d'abril de 2004 (Secció 2a, n. 557/2004, rec. 349/2002, ponent Miguel Soler Margarit), que, tot i atorgar una indemnització de 18.000 euros, no considera fet provat que la mort del pare de la recurrent tingués com a causa eficient el soroll, però sí una negativa incidència en la malaltia que patia.
} 
Aquesta sentència també resulta especialment interessant perquè, amb remissió a altres sentències de la mateixa Sala, entre d'altres a les de 16 de febrer o 29 de març de 2007 (que condemnen l'Ajuntament a adoptar les mesures necessàries per evitar els sorolls derivats de la infracció de l'horari de tancament de locals d'oci), considera que el domicili ha de ser objecte de protecció amb independència del fet que la construcció de l'habitatge pugui resultar il·lícita ${ }^{31}$, i va, per tant, més enllà que la jurisprudència del Tribunal Europeu ${ }^{32}, \mathrm{i}$, a més, rebutja també la prioritat de l'ús preexistent ${ }^{33}$.

Aquest mateix Tribunal, en la Sentència posterior de 6 de febrer de 2015 (Secció 2a, n. 99/2015, rec. 128/2014, ponent Acensión Martín Sánchez), respecte a les molèsties pels sorolls derivats de l'auditori municipal, a més de tornar descartar la teoria de la prioritat de l'ús preexistent, recull una posició més favorable pel que fa a l'acreditació dels danys, i els admet tot $\mathrm{i}$ que no en consti informe, si la seva causació resulta evident dels fets $^{34}$.

\footnotetext{
${ }^{31}$ La sentència afirma, després de fer referència a la jurisprudència del Tribunal Europeu de Drets Humans, que "el concepto de domicilio que debe tenerse en cuenta, según la jurisprudencia constitucional es más amplio del definido como tal por el art. 40 del Código Civil (punto de localización de una persona o lugar de ejercicio por esta de sus derechos u obligaciones). La protección constitucional del domicilio es una protección de carácter instrumental, que defiende los ámbitos en que se desarrolla la vida privada de la persona (STC 22/84, de 17 de febrero). Se trata de defender el ámbito de privacidad de la persona dentro del ámbito limitado que la propia persona elige. De ahí que a los efectos aquí discutidos, se estime irrelevante que las viviendas de los actores (aunque en alguno caso sean su segunda residencia) estén ubicadas en suelo no urbanizable [...], no susceptible de urbanización, ni de formación de núcleos residenciales [...] ya que si constituyen su domicilio es evidente que cualquier intromisión en el mismo, en los términos antes señalados, puede violar el art. $18 \mathrm{CE}$. Así lo demuestra el hecho notorio de que tal circunstancia no evitaría tener que solicitar un mandamiento de entrada para poder acceder al mismo sin el consentimiento de su titular salvo en caso de flagrante delito (art. 18 CE.) [...] Por lo demás el hecho de que el actor construyera un primer piso o buhardilla sin licencia y que fuera sancionado por tales hechos, no significa que la vivienda en cuestión no constituya su domicilio legal o que no tenga derecho a que se le protejan sus derechos fundamentales". En els mateixos termes, també es pronuncia la posterior Sentència del mateix Tribunal de 6 de febrer de 2015 (Secció 2a, n. 99/2015, rec. 128/2014, ponent Acensión Martín Sánchez).

${ }^{32}$ En l'assumpte Martínez Martínez i Pino Manzano contra Espanya, abans esmentat.

${ }^{33}$ La sentència afirma que "La STS 70/2001, de 2 de febrero, que habla del derecho a la calidad ambiental, rechaza explícitamente la «teoría de la preocupación»o de «la prioridad del uso preexistente», en virtud de la cual quienes, por ejemplo construyan sus viviendas cerca de un establecimiento industrial ya operativo tengan que soportar y tolerar las molestias causadas por el mismo, criterio que asimismo se recoge en la Sentencia de 18 de octubre de 2011 del TEDH, en caso Martínez Martínez contra España, en relación con un local de copas". Així també, la Sentència del Tribunal Superior de Justícia de Múrcia de 6 de febrer de 2015, tot seguit esmentada.

${ }^{34}$ La sentència afirma que "aunque no conste un informe de los daños psíquicos-morales [...] estar sometido a ruidos muy superiores a los permitidos, dentro de tu vivienda, aun con las ventanas cerradas, y con vibraciones en la vivienda, daños materiales acreditados, y no es preciso acreditar que estuviesen dentro de sus viviendas durante los conciertos, es notorio que afectan a la salud física y mental de los afectados".
} 
També la Sentència del Tribunal Superior de Justícia de Madrid de 5 de maig de 2011 (Secció 2a, n. 792/2011, rec. 396/2010, ponent Miguel Angel García Alonso) considera innecessària l'acreditació de danys a la salut perquè sorgeixi l'obligació d'indemnitzar ${ }^{35}$.

Quant a la determinació del quantum indemnitzatori, resulta interessant esmentar la Sentència del Tribunal Suprem de 2 de juny de 2008 (Secció 7a, rec. 10130/2003, ponent Pablo Lucas Murillo de la Cueva), la qual, amb esment de la Sentència de 14 d'abril de 2003, i partint del fet que el soroll priva del gaudi del domicili, calcula la quantia de la indemnització atenent al preu del lloguer d'un habitatge d'iguals característiques durant el temps comprès entre la primera sol-licitud no atesa i la data en la qual es duguin a terme les mesures que facin desaparèixer les pertorbacions.

Naturalment, una mínima actuació municipal, sense transcendència real sobre el problema, no eximeix l'Ajuntament de la responsabilitat pels danys derivats de la contaminació acústica $^{36}$, però sí una actuació diligent encara que no resulti satisfactòria per a la part particular afectada ${ }^{37}$.

\footnotetext{
${ }^{35}$ La sentència afirma que "el Tribunal Supremo en diversas sentencias de 10 de abril de 2003 y 23 de febrero y 24 de abril de 2004, declara que no es necesario, en consecuencia, y para que surja la obligación de indemnizar por parte de la administración demandada, la acreditación de la existencia de cualquier tipo de enfermedad producida por el ruido, lo cual serviría para incrementar en dicho caso el importe de la indemnización a fijar por esta Sala dependiendo de la enfermedad sufrida y tiempo de curación, siendo suficiente la acreditación de un ruido continuado y la incomodidad o sufrimiento experimentado".

${ }^{36}$ Així, les sentències del Tribunal Superior de Justícia de Madrid de 28 de gener de 2015 (Secció 2a, n. 31/2015, rec. 704/2013, ponent Juan Francisco López de Ontanar Sánchez) o del Tribunal Superior de Justícia de Múrcia de 6 de febrer de 2015 ja esmentada. També la Sentència del Tribunal Superior de Justícia de València de 26 de novembre de 2014 (Secció 1a, n. 1080/2014, rec. 302/2014, ponent Juan Francisco López de Ontanar Sánchez) afirma que:
}

[A]duce el apelante, de otro lado, que la lesión de los derechos fundamentales de los demandantes no sería en ningún caso imputable [...] a la pasividad municipal, ya que no hizo dejación de sus funciones, como lo evidencia el dato de que en ese año 2013 se cambiara la ubicación de la verbena [...] alejando de la vivienda de aquéllos el escenario alrededor de 25-30 metros.

Esta alegación ha de ser rechazada [...] El Ayuntamiento, a pesar de las numerosas denuncias y de los dictámenes aportados [...] en vía administrativa que revelaban la existencia de fuertes inmisiones acústicas en el interior de su vivienda generadas por otras verbenas anteriores [...] que ponían en evidencia, por tanto, la existencia de un riesgo constatado de producción cierta o al menos potencial de que se podían producir iguales o similares inmisiones acústicas [...] no adoptó ni la más mínima medida de control para asegurarse de que los ruidos producidos [...] no sobrepasaran el nivel sonoro previsto en la Ordenanza. Conviene resaltar que la Corporación Local incluso se había comprometido formalmente ante el Síndic de Greuges a realizar los trámites necesarios para el seguimiento y resolución satisfactoria de la queja planteada ante ese órgano en el año 2009 [...] relativa a las molestias acústicas generadas por las verbenas que cada año venía celebrando la falla. En definitiva, el Ayuntamiento hizo dejación de su posición de garante 
Finalment, no podem acabar aquest apartat sense esmentar també els problemes derivats del soroll causat per campanes en torres o edificis religiosos. En aquesta matèria, si bé en alguns casos s'han estimat els recursos interposats ${ }^{38}$, la jurisprudència se sol mostrar contrària atenent a les tradicions culturals i religioses ${ }^{39}$.

de los derechos de los vecinos, tolerando el incumplimiento por la falla de la regulación que él mismo había establecido (en este sentido, STC, Pleno, num. 150/11, antecitada).

Resulta interessant la Sentència del Tribunal Suprem de 12 de març de 2007 (Secció 7a, rec. 340/2003, ponent Eduardo Calvo Rojas). Com afirma GARCÍA ÁLVAREZ, G., es condemna l'Administració per inactivitat, tot i reconèixer que va adoptar diverses mesures, que no van donar resultat, però no totes les possibles ni les demanades pels perjudicats (la tramitació del procediment administratiu per declarar una zona acústicament saturada). Una anàlisi d'aquesta sentència es pot trobar a GARCÍA ÁLVAREZ, G., "La evolución del régimen jurídico del ruido", en Revista de Administración Pública, núm. 186, 2011, pp. 353-386.

${ }^{37}$ Per exemple, la Sentència del Tribunal Superior de Justícia de Catalunya de 8 de maig de 2013 (Secció 4a, n. 549/2013, rec. 142/2012, ponent Eduardo Barrachina Juan).

${ }^{38}$ Per exemple, la Sentència del Tribunal Superior de Justícia de Castella i Lleó d'1 de febrer de 2002 (n. 34/2002, rec. 453/2000, ponent José Luís López-Muñiz Goñi), si bé en aquell cas es tractava d'un rellotge.

${ }^{39}$ Així, es pot esmentar la Sentència del Tribunal Superior de Justícia de Navarra de 22 de febrer de 2011 (Secció 1a, n. 67/2011, rec. 336/2010, ponent Ignacio Merino Salva), cas en el qual s'al-legava un decret foral. El Tribunal afirma que aquesta no és l'única disposició existent, esmenta la normativa europea, estatal i l'ordenança municipal, i subratlla el caràcter veïnal de l'edifici de l'església i els seus components, i la seva antiguetat, tot i que distingeix entre les campanes i els rellotges acoblats, i afirma que "no hay problema que en cuanto a la llamada de la (s) campana(s) a los cultos religiosos se da en plenitud lo consuetudinario del aviso y reclamo (en su caso alarma) en vigor y en ello no se alberga duda; 90 decibelios. Mas no se entiende así en su totalidad respecto del reloj. En este apartado, se puede comprender que habida cuenta de un uso no ya local sino global de la utilización del reloj individual, el aviso horario de la torre-campanario a ella acoplado no tiene mayor razón de ser en su expansión sonora, sí del sonido, pero limitado. Nos referimos a que los avisos horarios del reloj, ante el uso social generalizado del elemento individual (de pulsera, cadena, electrónico, móviles etc.) ya no hace precisa esa expansión a 90 decibelios, con lo que en este apartado se puede y debe acomodar el límite sonoro a los términos del Decreto Foral 135/1989". També, en relació amb la impugnació d'una ordenança reguladora del soroll de les campanes, es pot esmentar la Sentència del Tribunal Superior de Justícia de Cantàbria de 6 de setembre de 2013 (Secció 1a, n. 493/2013, rec. 835/2011, ponent María Josefa Artaza Bilbao), la qual, amb esment de la jurisprudència del Tribunal Europeu de Drets Humans i del Tribunal Constitucional pel que fa a contaminació acústica, afirma que "el Tribunal Superior de Justicia de Cataluña, Sala de lo Contencioso-Administrativo, sec. $3^{\text {a }}$, en Sentencia de 17/06/2011, núm. 514/2011, rec. 99/2010, resalta el interés social y el arraigo del toque de campanas que radica en la cultura cristiana $\mathrm{y}$ en las costumbres de un determinado pueblo y es un hecho indiscutible y probado por notoriedad la presencia de la Iglesia y sus campanas desde hace siglos. Y de igual forma el Tribunal Superior de Justicia de Navarra Sala de lo Contencioso-Administrativo, sec. $1^{\text {a }}$, S 22-2-2011, num. 67/2011, rec. $336 / 2010$, considera «a priori» justificada en los usos y costumbres sociales la llamada de las campanas a los cultos religiosos y el reclamo en su caso alarma". En aquest punt, cal també esmentar les ordenances tipus reguladores del soroll i les vibracions elaborades per la Generalitat de Catalunya. L'article 23 del model A disposa que:

1. Qualsevol sistema d'alarma, campanes i sirenes o qualsevol altre sistema d'avís acústic que emeti a l'exterior o a l'interior de zones comunes, d'equipaments o de vehicles, s'ha de mantenir en perfecte estat de funcionament per evitar que s'activin per causes injustificades.

2. Llevat circumstàncies excepcionals no és permès fer sonar durant el període nocturn elements d'avís, com ara sirenes o alarmes. 


\section{La normativa administrativa}

La jurisprudència, com ja s'ha dit, ha actuat com a incentiu per al desplegament d'una normativa cada cop més abundosa pel que fa a contaminació acústica ${ }^{40}$. Així, cal destacar, en primer lloc, la Directiva 2002/49/CE, del Parlament europeu i del Consell, de 25 de juny, sobre avaluació i gestió del soroll ambiental ${ }^{41}$.

A Catalunya, mitjançant la Llei 16/2002, de 28 de juny, de protecció contra la contaminació acústica, es van establir les mesures necessàries per prevenir, corregir i controlar la contaminació acústica provocada per sorolls i vibracions. Posteriorment, l'Estat aprovà la Llei 37/2003, de 17 de novembre, del soroll, que transposa la Directiva 2002/49/CE. Aquesta llei es dictà a l'empara de les competències exclusives que l'article 149.1.16 i 23 de la Constitució li atribueixen pel que fa a les bases i coordinació general de la sanitat i legislació bàsica sobre protecció del medi ambient. En virtut d'aquest fonament competencial, les disposicions de la Llei 37/2003, de 17 de novembre, esdevenen normativa bàsica pel que fa al soroll ${ }^{42}$.

La necessitat de disposar dels criteris per elaborar mapes de capacitat acústica previstos a l'article 9 de la Llei 16/2002, de 28 de juny, motivà que, en aplicació del previst a

\footnotetext{
3. La regulació dels sistemes d'avís acústic s'ha d'ajustar al que preveu l'annex 8 [dedicat a la regulació del funcionament, nivells màxims i metodologia de mesurament per als avisadors acústics].

4. El toc de campanes, en horari nocturn, es condiciona als pactes establerts amb els responsables municipals, que en cap cas poden contravenir la legislació vigent.
}

L'article 24 afegeix que “quan l'anormal funcionament d'un sistema d'avís acústic produeixi molèsties al veïnat i no sigui possible localitzar al titular de la instal lació, l'Administració municipal pot desmuntar i retirar el sistema. Els costos originats per aquesta operació són a càrrec del titular de la instal·lació". En termes similars s'expressa l'article 14 del model B.

40 Descriu minuciosament l'evolució normativa en aquesta matèria GARCÍA ÁLVAREZ, G., "La evolución del régimen jurídico del ruido", en Revista de Administración Pública, núm. 186, 2011, pp. 353-386.

${ }^{41}$ El seu annex 2 ha estat modificat per la Directiva (UE) 2015/996 de la Comisió, de 19 de maig de 2015, per la qual s'estableixen mètodes comuns d'avaluació del soroll en virtut de la Directiva 2002/49/CE.

${ }^{42}$ Cal tenir present que, d'acord amb l'article 149.1.23a de la Constitució, que atribueix a 1'Estat la legislació bàsica sobre medi ambient, sens perjudici de les facultats de les comunitats autònomes d'establir normes addicionals de protecció, l'article 144.1 de l'Estatut d'autonomia de Catalunya atribueix a la Generalitat la competència compartida pel que fa a medi ambient (en el sentit de l'article 111, és a dir, incloent la potestat legislativa, la potestat reglamentària i la funció executiva, en el marc de les bases estatals) i la competència per a l'establiment de normes addicionals de protecció, competència que inclou, en tot cas, l'establiment i la regulació dels instruments de planificació ambiental i del procediment de tramitació i aprovació d'aquests instruments (apartat a), o la regulació de l'ambient atmosfèric i de les diverses classes de contaminació d'aquest (apartat c). També cal esmentar, com a competències connexes, entre d'altres, les competències pel que fa a protecció i promoció de la salut en tots els àmbits inclosa la sanitat ambiental (art. 162.3 b), o sobre habitatge (art. 137), o seguretat industrial (art. 139.1). 
l'apartat 1 d'aquest article, es dictés a Catalunya el Decret 245/2005, de 8 de novembre, pel qual es fixen els criteris per a l'elaboració dels mapes de capacitat acústica.

Per la seva part, el Reial decret estatal 1513/2005, de 16 de desembre, desplegà la Llei 37/2003, de 17 de novembre, del soroll, en la part referent a l'avaluació i gestió del soroll ambiental. Finalment, el Reial decret 1367/2007, de 19 d'octubre, desplegà la Llei 37/2003, de 17 de novembre, pel que fa a la zonificació acústica, objectius de qualitat $\mathrm{i}$ emissions acústiques ${ }^{43}$.

La incidència de la zonificació acústica en el planejament urbanístic i la necessitat que l'edificació incorpori les mesures necessàries per prevenir el soroll obliguen a tenir en compte també la Llei 21/2013, de 9 de desembre, d'avaluació ambiental, i el Reial decret 1371/2007, de 19 d'octubre, que aprova el document bàsic DB-HR, de protecció davant el soroll ${ }^{44}$.

Finalment, a Catalunya es dictà el Decret 176/2009, de 10 de novembre, pel qual s'aprova el Reglament de la Llei 16/2002, de 28 de juny, de protecció contra la contaminació acústica, i se n'adapten els annexos ${ }^{45}$, i el Decret 60/2015, de 28 d'abril, sobre les entitats col·laboradores de medi ambient ${ }^{46}$.

\footnotetext{
${ }^{43}$ La STS de 20 de juliol de 2010, de la Sala Tercera del Tribunal Suprem, anul·là l'expressió "sense determinar" que figurava en relació amb el tipus d'àrea acústica, f), dedicat a "Sectors del territori afectats a sistemes generals d'infraestructures de transport o altres equipaments públics que els reclamin", dins de la taula $\mathrm{A}$, que estableix els "Objetius de qualitat acústica per al soroll aplicables a àrees urbanes existents", de l'annex II del Reglament, dedicat als denominats "Objetius de qualitat acústica", del Reial decret 1367/2007, de 19 d'octubre. Una anàlisi d'aquesta sentència es pot trobar a GARCÍA ÁLVAREZ, G., "La evolución del régimen jurídico del ruido", Revista de Administración Pública, núm. 186, 2011, pp. 353-386. També mitjançant la STS de 19 de juny de 2012 (Secció 5a, rec. 64/2009, ponent: Jesús Ernesto Peces Morate) es desestimà el recurs interposat contra els articles 23.1, 23.2 i 23.4 del Reglament.

44 La Llei 38/1999, de 5 de novembre, d'ordenació de l'edificació, estableix, com a requisit bàsic de l'edificació, la "protecció contra el soroll, de manera que el soroll percebut no posi en perill la salut de les persones i els permeti dur a terme satisfactòriament les seves activitats" (article 3.1 c.2).
}

${ }^{45}$ Modificat pel Decret 60/2015, de 28 d'abril.

46 També en altres comunitats autònomes s'han dictat disposicions normatives per fer front al soroll. En aquest sentit, es poden esmentar, entre d'altres, la Llei 7/2010, de 18 de novembre, de protecció contra la contaminació acústica d'Aragó; la Llei 7/2002, de 3 de desembre, de la Generalitat Valenciana, de protecció contra la contaminació acústica, i el Decret 19/2004, de 13 de febrer, pel qual s'estableixen normes per al control del soroll produït pels vehicles de motor; el Decret 266/2004, de 3 de desembre, pel qual s'estableixen normes de prevenció i correcció de la contaminació acústica en relació amb activitats, instal-lacions, edificacions, obres i serveis, i el Decret 104/2006, de 14 de juliol, de planificació i gestió en matèria de contaminació acústica; la Llei 1/2007, de 16 de març, contra la contaminació acústica de les Illes Balears; la Llei 5/2009, de 4 de juny, del soroll de Castella i Lleó; la Llei 7/2011, de 5 d'abril, d'activitats classificades i espectacles públics i altres mesures administratives complementàries de la Comunitat Autònoma de Canaries; el Decret 19/1997, de 4 de febrer, de reglamentació de sorolls i vibracions de la Comunitat Autònoma d'Extremadura; el Decret 55/2012, de 15 de març, del Consell del Govern, pel qual s'estableix el régim legal de protecció contra la contaminació acústica en la Comunitat de Madrid; la Llei 4/2009, de 14 de maig, de protecció ambiental integrada de la Regió de Múrcia; la Llei 
Així mateix, i de conformitat amb l'article 84 de l'Estatut d'autonomia de Catalunya, que garanteix als ens locals competències pròpies en la formulació gestió de polítiques per a la protecció del medi ambient, i els articles 25 de la Llei 7/1985, de 2 d'abril, reguladora de les bases de règim local, o 66 del Decret legislatiu 2/2003, de 28 d'abril, pel qual s'aprova el Text refós de la Llei municipal i de règim local de Catalunya, tant la Llei estatal 37/2003 com la catalana 16/2002 i el Decret 176/2009 atribueixen competències en aquesta matèria als municipis, especialment l'elaboració d'ordenances (art. 6 de la Llei estatal o 21 de la Llei catalana), inspecció (art. 27 de la Llei catalana i article 7 del Decret) i sanció (art. 28 i 30 de la Llei estatal, o 37 i 38 de la Llei catalana). D’aquí es pot deduir la importància que l'actuació municipal té per protegir els ciutadans contra el soroll.

En qualsevol cas, amb anterioritat a tota aquesta normativa administrativa, els tribunals ja concedien una notable protecció contra les molèsties per sorolls. Es tracta, a més, d'una regulació d'un elevada complexitat tècnica, la qual, unida a una abundosa proliferació de normes, pot acabar suposant un autèntic obstacle per defensar els drets de les parts afectades. ${ }^{47} \mathrm{~A}$ més, tota aquesta normativa, en determinats aspectes, pot

3/1998, de 27 de febrer, general de protecció del medi ambient del País Basc; el Decret foral 135/1989, de 8 de juny, pel qual s'estableixen les condicions tècniques que han de complir les activitats emissores de sorolls o vibracions, i el Decret foral 193/1991, de 16 de maig, pel qual es modifica el Catàleg d'espectacles públics i activitats recreatives i les condicions tècniques d'activitats molestes per emissió de sorolls i vibracions, ambdós de la Comunitat Foral de Navarra; la Llei 7/2007, de 9 de juliol, de gestió integrada de la qualitat ambiental de la Comunitat Autònoma d'Andalusia, i el Decret 6/2012, de 17 de gener, pel qual s'aprova el Reglament de protecció contra la contaminació acústica a Andalusia; la Resolució de 25 d'abril de 2014, de la Conselleria de Foment, Ordenació del Territori i Medi Ambient, per la qual s'aprova la Instrucció tècnica per a l'avaluació i determinació de l'impacte acústic de les instal·lacions industrials en el Principat d'Astúries.

${ }^{47}$ En aquest sentit, i com afirma la Sentència de la Sala 1a del Tribunal Suprem de 19 de març de 2013 (n. 133/2013, rec. 1974/2010, ponent Francisco Marín Castán), “[1]o que busca el recurso, por tanto, es una dilución de responsabilidades en detrimento de quienes están sufriendo un daño tan cierto como evitable, sirviéndose las recurrentes de normas administrativas cuya recta interpretación no puede redundar en una disminución del grado de protección que el Código Civil y la Ley de Ordenación de la Edificación ofrecen frente a las inmisiones, sino en su fortalecimiento. Como esta Sala señaló en su sentencia num. $589 / 2007$, de 31 de mayo , podría sostenerse hasta cierto punto que «el muy notable y progresivo incremento de la normativa sobre esta materia (la de los daños a particulares por inmisiones medioambientales), de ámbito tanto estatal como autonómico e incluso local, no necesariamente se traduce en una mayor protección efectiva del particular frente al daño medioambiental que le afecta directamente, pues no pocas veces es la propia sobreabundancia de normas lo que dificulta la protección de sus derechos subjetivos» (FJ $3^{\circ}$ ). De aquí que, merced a la doctrina del Tribunal Europeo de Derechos Humanos, se haya producido una especie de retorno a lo fundamental permitiendo que sobre la maraña legislativa se imponga lo evidente, el derecho a la intimidad domiciliaria, y que frente a las inmisiones patentes pueda reaccionarse incluso por la vía de la protección civil de los derechos fundamentales y, cada vez más, por la vía penal, como demuestra el creciente número de sentencias de la Sala de lo Penal de este Tribunal Supremo ratificando penas cada vez más severas e indemnizaciones cada vez más elevadas a cargo de quienes perturban la vida de sus vecinos con inmisiones acústicas”. 
suposar un retrocés respecte a la protecció atorgada per la jurisprudència, havent estat objecte de crítiques per part de la doctrina ${ }^{48}$ per aquesta raó.

\section{Breu referència a un supòsit concret: el soroll derivat de l'activitat aeroportuària}

L'evolució jurisprudencial en aquest àmbit resulta especialment exemplificadora: així, des de posicions formalistes, com la de la Sentència del Tribunal Suprem de 27 d'abril

\footnotetext{
${ }^{48}$ Així, per exemple i sense un ànim exhaustiu, s'ha assenyalat que, mentre la Llei 37/2003, segons l'article 1, té per objecte "prevenir, vigilar i reduir la contaminació acústica", no eliminar-la, la jurisprudència ha aconseguit en molts casos suprimir-la. En aquest sentit, cal destacar que la Llei catalana 16/2002, de 28 de juny, amb un caràcter més protector que la Llei estatal, té per objecte, segons l'article 1, "prevenir i corregir la contaminació acústica". Així mateix, mentre la Llei 37/2003 exclou les immissions sonores patides per un membre de la comunitat de propietaris procedents d'un altre membre de la comunitat (atès que, segons l'article 2, "resten exclosos de l'àmbit d'aplicació d'aquesta Llei: a) les activitats domèstiques o els comportaments dels veïns, quan la contaminació acústica que produeixin es mantingui dins de límits tolerables de conformitat amb les ordenances municipals i els usos locals"), la jurisprudència ha concedit una àmplia protecció per mitjà de l'acció de cessació de l'article 7.2 de la Llei de propietat horitzontal, com veurem. Aquí també cal destacar que la Llei catalana 16/2002 inclou, en el seu àmbit d'aplicació (article 3), "qualsevol infraestructura, instal-lació, maquinària, activitat o comportament inclosos als annexos que originin sorolls i vibracions", i als annexos 3 i 4 determina els valors límit d'immissió i els valors d'atenció per les activitats i el veïnat. La 37/2003 tampoc es refereix a les indemnitzacions pels perjudicis causats. Per tant, la indemnització ha d'exigir-se per la via de l'article 1902 del Codi civil de 1888, sense que una llei del 2003 ho prevegi. En canvi, sí que preveu expressament aquesta indemnització la Llei catalana 16/2002, l'article 33.4 de la qual disposa que "La resolució que posa fi al procediment sancionador pot acordar, a més de la imposició de la sanció pecuniària que correspongui, l'adopció de mesures correctores i la indemnització per danys i perjudicis ocasionats com a conseqüència de l'actuació infractora". A més, seguint la Directiva 2002/49/CE, del Parlament europeu i del Consell, de 25 de juny de 2002, sobre avaluació i gestió del soroll ambiental, la Llei 37/2003 (articles 14 i ss) i també la Llei catalana 16/2002 (articles 4 o) i p), 9 o 23), preveuen l'elaboració de "mapes de soroll" o "mapes de capacitat acústica". Aquest aspecte ha estat criticat per la doctrina, que l'ha qualificat de "culte al decibel", i ha argumentat que implica que si en una determinada zona el límit es fixa en 40 decibels, no es pot afirmar que existeixi contaminació acústica si s'arriba als 39 decibels, i al titular d'un dret de propietat que es veu permanentment afectat per la contaminació acústica d'una activitat industrial o comercial no se li pot contestar que ha de patir la immissió per trobar-se, per exemple, en una determinada zona de soroll. Per tot això, la doctrina considera innecessària la prèvia zonificació acústica i l'elaboració de mapes acústics (MARTÍ I MARTÍ, J.), i critica el cost que suposa la seva elaboració (HERRERA DEL REY, J.J.). També s'ha criticat la previsió de plans d'acció (articles 22 i següents de la Llei 37/2003), que cal elaborar per a les grans infraestructures de transport i aglomeracions i per a les zones en què es comprovi l'incompliment dels objectius de qualitat acústica, i que tenen per objecte afrontar globalment les qüestions relatives a la contaminació acústica, determinar les accions prioritàries $i$ protegir les zones tranquil·les, afirmant que cal, no determinar accions a mig i llarg termini, sinó una solució immediata a situacions que poden suposar una vulneració de drets fonamentals. Aquesta crítica també és extensible als plans zonals específics (que l'article 25.3 de la Llei 37/2003 preveu per a una millora acústica progressiva de les zones de protecció acústica especial, en què s'incompleixen els objectius de qualitat acústica), o als plans de mesures per minimitzar l'impacte acústic que preveu l'article 38.2 de la Llei catalana 16/2002, i que han de preveure un termini plausible per assolir els valors límit d'immissió. També ha estat objecte de crítica la tipificació, com a sanció molt greu, a l'article 28.2 b) de la Llei 37/2003, "la superació dels valors límit que siguin aplicables quan s'hagi produit un dany o deteriorament greu per al medi ambient", atès que l'article 325 del Codi penal (que, per la seva naturalesa de delicte, constitueix una tansgressió més greu que una infracció administrativa) castiga la contaminació acústica encara que el dany efectiu no s'hagi materialitzat. Finalment, també s'ha criticat la Llei 37/2003 per la seva incidència en aspectes urbanístics, envaint competències autonòmiques (de fet, algun sector doctrinal - HERRERA DEL REY, J.J.-, l'ha qualificada de "llei urbanística d'escassa aplicabilitat"). En són exemples l'article 17 de la llei o l'article 13 del Reial decret 1367/2007.
} 
de 2004 (Secció 7a, rec. 8362/1999, ponent Fernando Martín González), respecte al soroll de l'aeroport del Prat en el barri Gavà-mar ${ }^{49}$, fins a la coneguda Sentència del Tribunal Suprem de 13 d'octubre de 2008 (Secció 7a, rec. 1553/2006, ponent Pablo Lucas Murillo de la Cueva), respecte al soroll de l'aeroport de Barajas sobre Ciudad de Santo Domingo.

En aquest últim cas, tot i la prèvia desestimació del recurs per la Sentència del Tribunal Superior de Justícia de Madrid de 31 de gener de $2006^{50}$, el Tribunal Suprem, després de recollir la doctrina del Tribunal Europeu de Drets Humans, considerà “indegudament formalista" la valoració del Tribunal Superior de Justícia, ja que tant els mesuraments aportats per les parts com els practicats en fase de prova eren "globalment expressius" d'una situació de contaminació acústica, i el soroll de fons només representava una mínima part del volum total, per la qual cosa no invalidava els resultats dels mesuraments.

El Tribunal Suprem afirma que el recompte del nombre, la freqüència, la intensitat $\mathrm{i}$ l'alçada dels vols permet afirmar el caràcter prolongat de la pertorbació (durant dos anys i mig més de 56.000 avions sobrevolaren Ciudad de Santo Domingo a una alçada mitjana de 655 metres, a intervals de menys de 3 minuts, i s'arribà a màxims de 78.3 decibels), i afegeix que el soroll és evitable, atès que existeixen rutes d'aproximació a l'aeroport que permeten evitar sobrevolar Ciudad de Santo Domingo, i la mateixa Administració ha arribat a admetre la possibilitat d'habilitar altres pistes per reduir la pertorbació. El Tribunal conclou instant l'Administració perquè adopti les mesures necessàries per al cessament de les pertorbacions ${ }^{51}$ i reconeix una indemnització a cadascuna de les parts demandants ${ }^{52}$.

\footnotetext{
${ }^{49}$ Aquesta sentència confirmà la del Tribunal Superior de Justícia de Catalunya de 21 d'octubre de 1999. No considera provada la intensitat del soroll (ja que no discrimina els mesuraments entre sons naturals $i$ artificials) ni la lesió en la integritat física o psíquica dels veïns, i destaca la preexistència de l'aeroport i que l'Ajuntament no adoptà mesures per frenar el creixement urbanístic, i conclou que no concorren ni la evitabilitat ni la insoportabilitat del soroll exigides pel Tribunal Constitucional.

${ }^{50}$ Entre d'altres raons, perquè no se superaven els valors de la declaració d'impacte ambiental de 1996, perquè no va considerar suficient l'informe pericial resultant dels mesuraments realitzats per un tècnic designat, a instància dels demandants, pel mateixTribunal, perquè no va discriminar el soroll procedent dels avions de la resta de sorolls procedents d'altres fonts, i perquè no va considerar prou argumentada la naturalesa evitable del soroll.

${ }^{51}$ La sentència afirma:
}

Apreciada la infracción del derecho a la intimidad domiciliaria, queda por determinar el alcance de la estimación parcial del recurso contencioso-administrativo. 
No obstant això, el Tribunal desestima l'al·legació de l'existència de la vulneració dels drets a la vida i a la integritat física i moral de les parts recurrents ${ }^{53}$. En la mateixa línia, també desestima aquesta al·legació la més recent Sentència del Tribunal Suprem de 14 de març de $2014^{54}$.

Com a reacció normativa que intenta garantir els interessos públics existents en el funcionament dels aeroports, cal assenyalar la Llei 5/2010, de 17 de març, que modificà la Llei 48/1960, de 21 de juliol, de navegació aèria, d'acord amb la seva exposició de motius, procurant "garantir el just equilibri entre els interessos de l'economia nacional i els drets dels propietaris dels béns subjacents",55.

Ciertamente, ha de comportar la declaración de la vulneración del derecho fundamental por la falta de acción de la Administración para evitar ese resultado.

Asimismo, ha de comprender el reconocimiento del derecho de los recurrentes a que cese esa situación. No obstante, no puede llegar nuestro pronunciamiento a establecer de qué manera ha de conseguirse ese resultado ya que nos lo impide la Ley de la Jurisdicción (artículo 71.2). Corresponde, pues, a la Administración competente adoptar las medidas adecuadas a tal fin.

52 D'aquesta sentència n'ha derivat una execució extraordinàriament complexa, amb diverses sentències del mateix Tribunal Suprem de dates 15 d'abril de 2011 o 7 d'octubre de 2013 (que l'han declarat inexecutada), i la Interlocutòria del Tribunal Superior de Justícia de Madrid de 2 de desembre de 2014.

${ }^{53}$ La sentència afirma que "hay que estar a lo señalado por el Tribunal Constitucional a propósito del artículo 15 de la Constitución. Es decir, al criterio [...] de que para atribuir a la acción u omisión de las Administraciones Públicas la vulneración del derecho a la integridad física o moral hace falta que los niveles de ruido a los que esté expuesto su titular causen daños graves e inmediatos en su salud o le coloquen en una situación en la que, sin llegar a producirse efectivamente ese daño, exista «un riesgo constatado de producción cierta, o potencial pero justificado ad casum, de la causación de un perjuicio para la salud». Es decir, que se acredite un riesgo relevante de que la lesión pueda llegar a producirse (STC 62/2007). Pero aquí, no ha llegado a probarse un riesgo de esa naturaleza".

${ }^{54}$ Segons aquesta sentència, "no consta que, en sí misma, esa afectación sea de la entidad necesaria para que vulnere el derecho fundamental a la integridad física, ni que obedezca únicamente a la contaminación acústica [...] Han quedado, en efecto, de manifiesto diferentes factores, de notable importancia y de reconocida capacidad de generación de estrés, que relativizan el efecto del ruido sobre la salud psíquica de los recurrentes, al dejarlo reducido a concausa. Además, esa misma circunstancia impide atribuirle el efecto de alterar con la gravedad necesaria su salud".

${ }^{55}$ Concretament, el seu article únic modifica l'article 4 de la susdita Llei 48/1960, i estableix, en el primer apartat, que "es reconeix el dret dels propietaris o ocupants dels béns subjacents a ser rescabalats de conformitat amb els capítols IX i XIII de la present Llei, la Llei 37/2003, de 17 de novembre, els tractats internacionals i el dret comunitari, dels danys i perjudicis que se'ls ocasionin com a conseqüència del seu deure de suportar la navegació aèria". El segon apartat afegeix que "el just equilibri entre els interessos de l'economia nacional i els drets de les persones residents, treballadores, propietàries, usuàries de serveis o ocupants de béns subjacents, obliga l'Estat, respecte dels aeroports de la seva competència: a) A garantir que per a les persones residents, treballadores, propietàries, usuàries de serveis o ocupants de béns subjacents a les poblacions circumdants dels esmentats aeroports es respectin els objectius de qualitat acústica que fixa la normativa aplicable. Sempre que es compleixin aquests objectius és obligatori suportar els nivells sonors, sobrevols, freqüències i impactes ambientals generats per la navegació aèria, sense perjudici del dret dels afectats a denunciar els incompliments de la normativa aeroportuària 0 aeronàutica que es puguin produir i a sol-licitar que es reparin”. Entre altres mesures, es preveu l'aprovació de plans d'acció, que han de preveure mesures compensatòries per als municipis en els quals se superin els objectius de qualitat acústica en l'exterior de les edificacions; l'avaluació continuada, 
Amb posterioritat a aquesta modificació legislativa, es poden esmentar les sentències de l'Audiència Nacional d'11 de març de 2013 (Secció 1a, rec. 430/2011, ponent Javier Bermudez Sánchez) o de 4 de novembre de 2013 (Secció 8a, rec. 766/2009, ponent José Alberto Fernández Rodera), en relació amb reclamacions de responsabilitat patrimonial per sorolls derivats de l'aeroport de Barajas i de l'aeroport del Prat, respectivament.

Les sentències es remeten a l'anterior Sentència de la mateixa Sala de 20 de desembre de 2012 (Secció 1a, rec. 398/2010, ponent María Nieves Buisan García), i, després de fer referència a la jurisprudència del Tribunal Europeu de Drets Humans sobre el soroll aeroportuari i a la Sentència del Tribunal Suprem de 13 d'octubre de 2008 ("dada su gran similitud con el supuesto ahora planteado"), desestimen els recursos.

La mateixa Sala reconeix que tingué dubtes sobre la constitucionalitat de la modificació operada per la Llei 5/2010, però acaba considerant que n'és possible una interpretació conforme a la Constitució, basant-se en la necessitat de garantir un just equilibri entre els interessos generals i els particulars, d'acord amb la jurisprudència del Tribunal Europeu de Drets Humans ${ }^{56}$. Finalment assenyala que es compleixen els objectius de qualitat acústica, i quant a la aplicació retroactiva de la modificació legislativa, aprovada mentre es tramitava el recurs i que podria ser considerada restrictiva de drets individuals i prohibida per l'article 9.3 de la Constitució, considera que només es

vigilància i sanció dels incompliments, l'adopció de les mesures pertinents per compatibilitzar l'explotació de l'aeroport amb els drets dels propietaris o ocupants dels béns contigus o la creació d'una comissió mixta en cada aeroport que pot consultar representants sindicals, empresarials i veïnals.

56 La sentència afirma que "Esta Sala tuvo dudas, en un primer momento, sobre la posible inconstitucionalidad de dicha modificación legislativa, concretamente en lo referente a la obligación de soportar los niveles sonoros [...] por su posible contravención con el artículo 106.2 de la Constitución y también con los artículos 24 (tutela judicial efectiva) y 18.1 (intimidad domiciliaria) de la misma" però considera que "es posible efectuar una interpretación conforme a la Constitución" atenent al fet que "la obligación de soportar los niveles sonoros fijados en la normativa aplicable se supedita por tal Ley 5/2010 al principio del justo equilibrio entre los intereses de la economía nacional y los derechos de tales ocupantes de bienes subyacentes (piedra angular de la reforma, de conformidad con la Jurisprudencia del Tribunal Europeo citada)". La Sala assenyala, a més, que el nou article 4 estableix obligacions per a l'Estat, com la d'indemnitzar les parts perjudicades, i recorda a més "que una sociedad económica y tecnológicamente avanzada, necesariamente ha de comportar un cierto nivel de ruido (inevitable como consecuencia del tráfico aéreo) [...] Sin que pueda concluirse, de la lectura del nuevo artículo 4 de la Ley de Navegación Aérea, que el mismo implique una exposición prolongada a unos determinados niveles de ruido que puedan calificarse de evitables e insoportables. El Tribunal conclou afirmant que "que la obligación de soportar los niveles sonoros generados por la navegación aérea, establecida en la nueva redacción del precepto, ha de ponderarse, de un lado, con el interés que para el desarrollo de la economía nacional y el empleo supone la nueva infraestructura aeroportuaria objeto de esta litis y, además, con el obligado cumplimiento de los objetivos de calidad acústica que el mismo precepto impone al Estado". 
tractaria d'una retroactivitat impròpia que, per tant, no vulneraria la prescripció constitucional $^{57}$.

\section{Referència a un altre supòsit concret: la celebració de festes locals}

La celebració de festes locals ${ }^{58}$ implica, òbviament, un augment dels nivells de soroll

habituals, i per això ha generat, a més de les ja habituals reclamacions de responsabilitat patrimonial, la presentació de sol·licituds de suspensió o trasllat de les festes ${ }^{59}$.

Certament, la festa local es troba íntimament unida a interessos polítics, socials, culturals, i, cal no oblidar-ho també, econòmics, especialment en la seva vessant turística. De fet, sol ser l'autoritat municipal la que organitza o dóna suport a aquesta mena de festes ${ }^{60}$.

El problema sorgeix quan els ajuntaments utilitzen les seves competències, no per evitar la contaminació acústica, sinó per legitimar-la. La festa, òbviament, no pot suposar una derogació, encara que temporal, dels drets fonamentals dels ciutadans per decisió de l'autoritat municipal.

\footnotetext{
${ }^{57}$ Més recentment, i pel que fa al soroll aeroportuari, també es pot esmentar la Sentència del Tribunal Superior de Justícia de Madrid de 29 d'octubre de 2015 (Secció 8a, n. 629/2015, rec. 283/2006), en la qual desestima el recurs, i destaca els defectes en els mesuraments aportats pels recurrents. Aquest, com anirem veient, és un problema constant en totes les jurisdiccions.

${ }^{58}$ En aquest apartat, seguim LAFUENTE BENACHES, M. M., "La contaminación acústica en las fiestas locales", en "El Cronista del Estado Social y Democrático de Derecho", núm. 13, 2010, pp. 70-77.

${ }^{59}$ En aquest sentit, la Sentència del Tribunal Superior de Justícia de Canàries de 22 de juliol de 2002 (Secció 1a, n. 492/2002, rec. 819/1997, ponent Jaime Borrás Moya) estimà la petició de trasllat de les casetes de Carnestoltes, sentència confirmada pel Tribunal Suprem en la seva Sentència de 13 d'abril de 2005 (Secció 4a rec. 8343/2002, ponent Mariano Baena del Alcázar); també es pot esmentar la coneguda Sentència d'aquest mateix Tribunal Superior de 27 de gener de 2007 (Secció 1a, n. 14/2007, rec. 219/2006, ponent M ${ }^{a}$ Pilar Alonso Sotorrio), que optà pel manteniment del Carnestoltes, atesa la seva importància, però assenyalà la conveniència d'adoptar totes les mesures que fossin necessàries, $i$ fins $i$ tot arribà a traslladar les activitats noctures; la Sentència del Tribunal Superior de Justícia de Madrid de 17 de gener de 2008 (n. 340/2008, rec. 613/2007, ponent Miguel Angel García Alonso), acordà la suspensió de la festa local en la seva ubicació actual fins a la valoració de la seva incidència acústica.

${ }^{60}$ Així, la Sentència del Tribunal Superior de Justícia de Balears de 23 de febrer de 2006 (Secció 1a, n. 196/2006, rec. 588/2003, ponent Fernando Socias Fuster) qualifica l'Administració com a organitzadora de facto, i afirma que, d'acord amb la jurisprudència del TS, no pot eludir la seva responsabilitat ni pel caràcter popular de la festa ni per remissió a la responsabilitat de l'empresa contractada (amb esment de les sentències del Tribunal Suprem de 3 de maig de 2001 o 13 de setembre de 1991); la Sentència del Tribunal Suprem de 27 de desembre de 1999 (Secció 6a, rec. 6998/1995, ponent Jesús Ernesto Peces Morate), com a coorganitzadora, i precisa que el fet que la seva preparació i execució corresponguessin a un tercer no l'allibera de responsabilitat; també la Sentència del Tribunal Superior de Justícia de Castella i Lleó de 15 de desembre de 2006 (Secció 3a, n. 2236/2006, rec. 1970/2000, ponent Lallana Duplá, M ${ }^{\text {a }}$ Antonia), amb esment de la Sentència del Tribunal Suprem de 13 de setembre de 1991, afirma la responsabilitat de l'Administració fins i tot encara que es cedeixi la seva gestió a comissions o entitats amb personalitat independent.
} 
Un clar exemple és el que esmenta MARÍA MERCEDES LAFUENTE BECNACHES $^{61}$ : així, mentre la Llei estatal 37/2003 preveu, a l'article 9, que "Amb motiu de l'organització d'actes d'especial projecció oficial, cultural, religiosa o de naturalesa anàloga, les administracions públiques competents poden adoptar, en determinades àrees acústiques, prèvia avaluació de la incidència acústica, les mesures necessàries que deixin en suspens temporalment el compliment dels objectius de qualitat acústica que hi siguin aplicables", la Llei valenciana 7/2002, de 3 de desembre, de protecció contra la contaminació acústica, a la disposició addicional primera, titulada "Situacions especials", no exigeix valoració de la incidència acústica ni l'adopció de mesures necessàries, i no parla de suspensió sinó, directament, d'exempció ${ }^{62}$. En conseqüència, l'Ordenança municipal de l'Ajuntament de València, de 30 de maig de 2008, de protecció contra la contaminació acústica, en la disposició addicional primera, conté una enumeració d'exempcions molt extensa i indeterminada, sense preveure mesures per pal·liar els possibles excessos acústics (només per a algun supòsit específic es fa referència a la necessitat de demanar autorització o d'advertir el públic) ${ }^{63}$.

\footnotetext{
${ }^{61}$ En l'article esmentat a la nota 53.

${ }^{62}$ Els dos primers apartats de l'esmentada disposició estableixen que:
}

1. L'autoritat competent per raó de la matèria a la qual pertanya la font generadora del soroll o vibracions podrà eximir, amb caràcter temporal, del compliment dels nivells de pertorbació màxims fixats en la present llei en determinats actes de caràcter oficial, cultural, festiu, religiós i altres anàlogues.

2. El titular de l'activitat, instal·lació o maquinària causant de la pertorbació acústica, o en el seu defecte l'administració autoritzant, informarà al públic sobre els perills d'exposició a elevada pressió sonora, recordant el llindar dolorós de $130 \mathrm{~dB}(\mathrm{~A})$ establert per les autoritats sanitàries.

${ }^{63}$ L'Ordenança disposa que

De conformidad con lo establecido en la disposición adicional primera de la Ley 7/2002, de 3 de diciembre, de la Generalitat Valenciana, de protección contra la contaminación acústica, la autoridad competente por razón de la materia a que pertenezca la fuente generadora del ruido o vibraciones podrá eximir, con caràcter temporal, del cumplimiento de los niveles de perturbación máximos fijados en la presente ordenanza en determinados actos de carácter oficial, cultural, festivo, religioso, deportivo y otros análogos, y en particular quedan eximidos los siguientes actos tradicionales:

1. Los espectáculos pirotécnicos siempre que dispongan de las autorizaciones o licencias que les correspondan de conformidad con su normativa sectorial.

2. La cabalgata de Reyes.

3. Los actos propios de la festividad de San Antonio Abad que tradicionalment se celebran en la calle Sagunto.

4. Los actos institucionales propios de la festividad de San Vicente Mártir, Patrono de la Ciudad de Valencia. 
Aquesta ordenança, més que protegir els ciutadans, dóna cobertura a l'Administració local per legitimar actuacions que, d'una altra manera, serien il·legals i per eximir-la de possibles responsabilitats davant d'eventuals reclamacions dels ciutadans ${ }^{64}$.

\begin{abstract}
5. En la Fiesta de Fallas, los actos previstos en el programa oficial. Asimismo, los actos que se desarrollan en la vía pública por las distintas Comisiones, y consistentes en pasacalles, desfiles, actividades y juegos infantiles, representaciones teatrales, balls al carrer, verbenas, y otros similares que cuenten con la correspondiente autorización administrativa. Por bando de Alcaldía se fijará el número de fechas habilitadas para la celebración de verbenas o similares.
\end{abstract}

6. En la Semana Santa Marinera, los actos colectivos, así como los actos individuales que celebran las diferentes Cofradías, Hermandades y Corporaciones integradas en la Junta Mayor de la Semana Santa Marinera.

7. Las representaciones de los milagros por los diferentes Altares con ocasión de la festividad de San Vicente Ferrer, Patrono de la Comunidad Valenciana.

8. Los actos propios y tradicionales que se celebran con ocasión de la celebración de las festividades de la Virgen y del Corpus.

9. En San Juan, los actos festivos desarrollados por las distintas entidades ciudadanas, tales como hogueras, verbenas y similares.

10. En la Feria de Julio, los actos previstos en el programa oficial.

11. En la festividad del 9 de octubre, los actos previstos en el programa oficial. También los desarrollados con carácter tradicional por las Agrupaciones de Moros y Cristianos, tales como embajadas, representaciones teatrales y similares, y que dispongan de autorización administrativa.

\title{
12. La tradicional feria de atracciones de Julio y Navidad.
}

13. En las fiestas que se desarrollan en los distintos barrios y pedanías de la Ciudad con carácter tradicional, y que cuenten con autorización administrativa.

14 Los eventos deportivos consistentes en la celebración de pruebas con vehículos de motor en la ciudad de Valencia y los actos de todo tipo conexos al mismo (entrenamientos, pruebas, etc.). En especial, la celebración de pruebas con motivo del campeonato de Fórmula Uno.

En todos estos supuestos, cuando tradicionalmente conlleven la realización de toques de campana de carácter manual, se eximen del cumplimiento de los niveles de perturbación máximos establecidos, los citados toques, por su valor histórico y patrimonial, especialmente en el caso del Campanario de la Catedral de Valencia.

Todo ello sin perjuicio del cumplimiento de lo dispuesto en el artículo 19 de la presente Ordenanza, respecto a la limitación del nivel sonoro durante la celebración de verbenas, así como de lo dispuesto en el artículo 4, respecto a la información al público sobre los peligros de exposición a elevada presión sonora, recordando el Umbral doloroso de 130 dBA establecido por las autoridades sanitarias.

${ }^{64}$ Molt més protectores davant del soroll resulten les ordenances tipus reguladores del soroll i les vibracions elaborades per la Generalitat de Catalunya. A més de la Llei 16/2002 (que a l'article 21.3 preveu que "Les ordenances poden tenir en compte les singularitats pròpies del municipi, com ara les activitats festives i culturals, i les que tenen un interès social, sempre que tinguin un cert arrelament"), i del Decret 176/2009 (que a l'article 7 atribueix als ajuntaments la suspensió provisional dels objectius de qualitat acústica i a l'article 38.3 preveu aquesta suspensió sempre que s'acrediti que les millors tècniques disponibles no permeten el compliment dels objectius de la suspensió que es pretén), l'article 9 del model A i l'article 6 del model B, titulats "Suspensió dels objectius de qualitat acústica", als seus primers tres apartats, disposen que: 
1. L'Ajuntament, per causes degudament justificades, pot autoritzar la suspensió provisional dels objectius de qualitat acústica aplicables a la totalitat o part d'una zona acústica.

2. Els titulars d'emissors acústics poden sol·licitar a l'ajuntament, per raons degudament justificades, que han d'acreditar-se en el corresponent estudi acústic, la suspensió provisional dels objectius de qualitat acústica aplicables a la totalitat o part d'una zona o àrea acústica.

3. L'ajuntament només pot acordar la suspensió provisional, prèvia valoració de la incidència acústica, sempre que s'acrediti que les millors tècniques disponibles no permeten el compliment dels objectius esmentats. L'ajuntament ha de sotmetre la suspensió a les condicions que s'estimin pertinents.

L'article 15 del model A i 10 del model B afegeixen que:

1. Les terrasses, fires d'atraccions, mercats, parades de venda ambulant, espantalls acústics $i$ totes les altres activitats a l'aire lliure que tinguin una incidència acústica significativa han de disposar d'autorització municipal expressa, la qual ha d'assenyalar les condicions a complir per minimitzar la seva possible incidència a la via pública segons la zona on tinguin lloc.

2. A les terrasses d'ús públic, la instal·lació de qualsevol mena d'element acústic extern o de megafonia, així com la realització d'actuacions en viu, han de disposar d'autorització expressa.

3. Els envelats i les discoteques a l'aire lliure han de disposar d'un limitador-enregistrador, d'acord amb l'establert a l'Annex 10 per tal d'assegurar que no se superin els valors límit establerts.

L'article 16 del model A i 11 del B, amb el títol "Activitats festives i altres actes a la via pública", disposen el següent:

1. Les revetlles, festes tradicionals, fires, cercaviles, espectacles musicals o d'altres manifestacions populars a la via pública o en altres àmbits d'ús públic o privat a l'aire lliure, així com els actes cívics, culturals, reivindicatius, esportius, recreatius excepcionals, fires d'atraccions, mítings i tots els altres que tinguin un caràcter semblant, han de disposar d'autorització municipal expressa, la qual ha d'assenyalar les condicions a complir per minimitzar la possible incidència dels sorolls a la via pública segons la zona on tinguin lloc.

2. Les activitats públiques que utilitzin sistemes electroamplificats de so han d'assegurar que el nivell sonor màxim no superi els $100 \mathrm{~dB}(\mathrm{~A})$ (LAeq,60s) als indrets d'accés públic $\mathrm{i}$ el nivell màxim de $80 \mathrm{~dB}(\mathrm{~A})$ (LAeq, 30 minuts)a la façana més exposada.

3. En els casos que es consideri oportú, l'ajuntament pot exigir la instal·lació d'un limitador-enregistrador o altres mecanismes similars, per garantir que no se superin els nivells d'immissió.

4. En cas d'incompliment de les condicions i mesures establertes als apartats anteriors, i sens perjudici de les responsabilitats que es derivin de la infracció, l'ajuntament pot adoptar les mesures necessàries, inclosa la suspensió de l'activitat.

Així mateix, l'article $17 \mathrm{del}$ model A, titulat "Instal·lacions amb sistemes de megafonia”, estableix que:

1. L'horari de funcionament dels sistemes de megafonia i els equips de música amplificada de les instal·lacions a l'aire lliure, tant públiques com privades, comprèn entre les $8 \mathrm{~h}$ i les 23 hores els dies laborables de dilluns a divendres i entre les $9 \mathrm{~h}$ i les $23 \mathrm{~h}$ els dissabtes, diumenges i festius.

2. Aquests sistemes han de ser direccionals, i han d'estar orientats cap a les instal·lacions. $\mathrm{S}$ 'han d'utilitzar de manera adequada i respectuosa tant en el volum com en la freqüència.

3. En tot cas, no es poden superar els valors límit d'immissió establerts.

Finalment, l'article 18 del model A, titulat "Espectacles pirotècnics", disposa que "Els espectacles pirotècnics i l'ús de petards s'han de dur a terme, com a mínim, a 200 metres de distància dels edificis hospitalaris o espais que l'ajuntament consideri que cal preservar." 
Com afirma el Tribunal Superior de Justícia de València, en la Sentència de 25 de juny de 2003 (Secció 3a, n. 1122/2003, rec. 268/2003, ponent Edilberto José Narbón Lainez), "no es objeto de discusión que las fallas son una fiesta popular en Valencia, ahora bien, el hecho de que una fiesta sea popular no significa que esté por encima de toda regla y toda norma"65. Tanmateix, en la Sentència d'11 de desembre de 2009 (Secció 1a, n. 1724/2009, rec. 568/2008, ponent Edilberto José Narbón Lainez), aquest mateix Tribunal adopta una posició molt favorable a la festa ${ }^{66}$, i també ho fa en la Sentència de 17 de setembre de 2013 (Secció 1a, n. 903/2013, rec. 1049/2012, ponent Edilberto José Narbón Lainez), entenent que la temporalitat de la festa fa que no es puguin afirmar vulnerats els drets fonamentals de les parts afectades ${ }^{67}$.

${ }^{65}$ La Sentència de 25 de gener de 2007 afegeix que "las autoridades competentes (Generalidad Valenciana, Ayuntamiento), tan pronto detecten que alguna industria o local està incumpliendo la normativa vigente sobre transmisión de ruidos [...] tienen la obligación [...] de impedirlo adoptando las medidas adecuadas y, de no hacerlo, se convierten en corresponsables de la vulneración de la legalidad".

${ }^{66}$ La sentència es remet a l'anterior 293/1998, segons la qual "una cosa es que los casales falleros, durante la semana de fallas, presentación de la fallera mayor etc. organicen actividades que ciertamente van a producir ruidos y molestias al vecindario donde se ubican, en cuyo caso bastará la autorización municipal de los arts. 10 y 12 de la Ley de las Cortes Valencianas 2/1991, de 18 de Febrero, de Espectáculos, Establecimientos públicos y Actividades Recreativas y, otra cosa diferente es destinar un local a bar con ambiente musical con carácter o vocación de permanencia, en el primer caso, nos encontraríamos con la tradición fallera que, evidentemente tiene por naturaleza un componente ruidoso importante; en el segundo, una actividad que causa ruidos y molestias con cierta asiduidad y continuidad y que son evitables mediante medidas correctoras. Desde el punto de vista del que recibe los ruidos hay una diferencia importante, si no quiere recibir ruidos en la semana fallera le bastará con marcharse, lo que no puede hacer ni se le puede obligar es a desalojar su domicilio los fines de semana, algunos laborales, o períodos largos de tiempo, en definitiva, en este segundo caso se está violando el derecho al disfrute tranquilo de su domicilio". Per tant, d'acord amb aquesta argumentació del Tribunal, durant les festes, els veïns afectats hauran de marxar de la ciutat, sense que es tinguin en compte en aquesta migració ni la seva capacitat econòmica per marxar, ni si el seu estat de salut els ho permet, conclusions que semblen difícilment acceptables.

${ }^{67}$ La sentència afirma que "esta Sala no ignora que durante las fiestas patronales de una localidad la Generalidad Valenciana puso en manos de los Municipios tanto la fijación de horarios como los excesos de ruido en la disposición adicional primera de la Ley 7/2002, de 3 de diciembre, de Protección contra la contaminación acústica, recogido en el ordenanza municipal". El Tribunal considera que l'Ajuntament no ha incorregut en inactivitat, atès que "los escritos que ha presentado la parte demandante han sido contestados [...], es decir, no existe inactividad formal ni material”, i afirma que, si bé el resultat de les medicions sobrepassaria el règim general de la Llei 7/2002, no s'han vulnerat els drets fonamentals dels articles 15 i 18 de la Constitució perquè es tracta d'un règim excepcional "durante dos semanas al año (enero y septiembre), no se trata de una actividad continuada ni el actor ha acreditado las concretas circunstancias para que el Tribunal entienda que se han vulnerado el art. 15 o el art. 18 CE."

Tot i això, el Tribunal precisa que "Respecto de dichas «fiestas populares», la Sala quiere dejar claro que la discrecionalidad de la Administración Municipal no puede derivar en arbitrariedad, es decir, no es posible interpretar que en el municipio de Benicasim durante dos semanas al año no exista control de actividades, horarios ni contaminación acústic". És a dir, segons la Sala, dins d'aquest règim excepcional s'han d'establir horaris i límits i ha d'existir un control del seu compliment, ja que "no todos los ciudadanos que viven en Benicasim trabajan en dicha ciudad y se pueden permitir dos semanas de vacaciones". Ara bé, els posibles incompliments d'aquest règim excepcional només constituirien una qüestió de legalitat ordinària: "La falta de control, si bien sera difícil por las razones expuestas que pueda vulnerar derechos fundamentales, incurrirá en arbitrariedad y pude ser anulado o suspendido por la Sala 
També en aquesta línia, la Sentència del Tribunal Superior de Justícia de Cantàbria de 9 de març de 2011 (Secció 1a, n. 165/2011, rec. 176/2010, ponent María Josefa Arteza Bilbao) denegà la mesura cautelar de suspensió dels actes festius sol·licitada perquè no $\mathrm{s}^{\prime}$ havien acreditat els nivells de soroll i pels interessos generals presents ${ }^{68}$, i la Sentència del Tribunal Superior de Justícia de Madrid de 5 de maig de 2011 (Secció 2a, n. 792/2011, rec. 396/2010) sostingué la constitucionalitat i la conformitat al dret comunitari de l'esmentat article 9 de la Llei 37/2003, basant-se també en la temporalitat del soroll (tot i que validà la suspensió de les festes acordada en la instància "hasta que se valorase la incidencia acústica y se concretasen formalmente las medidas necesarias para disminuir en lo posible las molestias a los vecinos de la zona") ${ }^{69}$.

En contra de considerar la temporalitat de la pertorbació com a element que impedeix considerar vulnerats els drets fonamentals ${ }^{70}$, es pronuncia la Sentència del Tribunal Superior de Justícia de València, de 26 de novembre de 2014 (Secció 1a, n. 1080/2014,

ante un recurso por legalidad ordinaria, vía interpretación del concepto de discrecional y los principios generales del derecho". En conseqüència, sembla que cal entendre que durant les festes, les incidències acústiques no afectarien els drets fonamentals, encara que incompleixin la pròpia normativa reguladora de la festa (més laxa que la normativa ordinària) i encara que puguin ser més greus que les que, durant la resta de l'any, ja es consideren vulneradores d'aquests drets, conclusió que, naturalment, sembla difícil de compartir.

${ }^{68}$ La sentència afirma que "ya que de lo que se trata es de la suspensión de cualquier fiesta, entre ellas, las de mayor transcendencia e importancia de la ciudad $\mathrm{y}$, su adopción de la medida de prohibición indiscriminada, produciría gran perjuicio a la Sociedad [...] lo que dañaría sin duda la libertad y derecho de terceros".

${ }^{69}$ Respecte a la conformitat amb la Directiva 2002/49/CE, la sentència afirma que "la citada Directiva se refiere al ruido ambiental, configurado como producido de modo permanente que exige la elaboración de mapas de ruido. Este no es el supuesto y no es de aplicación esta Directiva ya que nos encontramos ante un ruido producido con carácter extraordinario y temporal, como consecuencia de unas fiestas populares".

Quant a la constitucionalitat del precepte, afirma que "como norma general los festejos populares de carácter temporal se consideran necesarios en cuanto forman parte de nuestra cultura y el ruido emitido va a conllevar que se superen los límites ordinarios de ruido. Es evidente que el ruido intenso, prolongado y sin ningún tipo de limitaciones, sí afecta a la salud y al descanso de los vecinos de acuerdo con lo declarado por el Tribunal Constitucional y el Tribunal Supremo en el fundamento anterior. Sin embargo la Sala entiende como innecesario el planteamiento de cuestión de inconstitucionalidad con relación al art. 9 de la Ley del Ruido: debe recordarse que este artículo exige para que se pueda dejar en suspenso el cumplimiento de los objetivos de calidad acústica que sean de aplicación, "que se adopten las medidas necesarias, previa valoración de la incidencia acústica". Por tanto este artículo está exigiendo que cuando las administraciones públicas organicen la celebración de fiestas populares tienen que valorar el ruido que se pueda emitir y especialmente deben limitar con carácter previo tanto su nivel de intensidad como los horarios en el que se produce con el fin de permitir el descanso de los vecinos".

70 Per tant, més en la línia apuntada per la Sentència del Tribunal Europeu de Drets Humans en l'assumpte Zammit Maempel contra Malta, de 22 de novembre de 2011. 
rec. 302/2014, ponent $M^{a}$ de los Desamparados Iruela Jiménez), tot i que es tractava d'un supòsit de contaminació acústica d'una notable intensitat ${ }^{71}$.

\section{LA PROTECCIÓ EN L’ÀMBIT CIVIL}

En l'ordre civil, la protecció contra el soroll s'ha articulat fonamentalment des de la perspectiva de la culpa extracontractual, des de les relacions de veïnatge per immissions acústiques, des del règim de la propietat horitzontal o des de la perspectiva de la tutela del dret a la intimitat (amb una interpretació extensiva i sociològica de la Llei orgànica 1/1982, de 5 de maig, de protecció civil del dret a l'honor, a la intimitat personal i familiar i a la pròpia imatge).

La Sentència del Tribunal Suprem de 5 de març de 2012 (n. 80/2012, rec. 2196/2008, ponent Francisco Marín Castán), basant-se en la jurisprudència del Tribunal Europeu de Drets Humans, situa la protecció contra el soroll en l'àmbit de la tutela judicial civil dels drets fonamentals, i admet naturalment també la tutela a l'empara de la legislació civil ordinària. La Sentència del Ple del Tribunal Suprem de 12 de gener de 2011 (n. 889/2010, rec. 1580/2007, ponent Francisco Marín Castán) constata que, a partir de la Sentència de 29 d'abril de 2003, la jurisprudència ha incorporat la doctrina del Tribunal Europeu de Drets Humans segons la qual determinades immissions poden vulnerar drets

\footnotetext{
71 La sentència, després de recordar la jurisprudència del Tribunal Europeu de Drets Humans i del Tribunal Constitucional, rebutja l'argument de l'Ajuntament, segons el qual, perquè existeixi una efectiva vulneració de drets fonamentals, cal un soroll continuat en el temps, no limitat a tres dies com en aquell cas. La Sala entén que no només és determinant el temps d'exposició, sinó també la intensitat d'aquesta exposició: "como manifiesta la STS 3a, Sección 7a, de 10 de junio de 2013 recurso de casación número 6500/2011—, lo fundamental es que la entidad y duración de la exposición a ruidos evitables e insoportables sea tal que merezca la protección dispensada a aquellos derechos fundamentales [...] Y en el caso de autos [...] tales mediciones ofrecen información más que suficiente [...] tratándose de niveles sonoros que exceden de forma continua los niveles de inmisión sonora máximos admisibles tanto en horario nocturno como diurno, siendo los valores elevadísimos, muy por encima de los máximos tolerables indicados en la normativa vigente. De forma sumamente ilustrativa de la elevada intensidad de la repercusión del ruido en la vivienda, añade el perito que el nivel sonoro evaluado dentro del dormitorio es similar al que se puede encontrar en una autopista con tránsito, y cuando se abren las ventanas los niveles sonoros son equiparables a los que se dan dentro de un pub con ambientación musical. Es obvio, por tanto, que la exposición de los actores durante tres días seguidos en horario nocturno, desde las 23:00 horas hasta las 4:00 del día siguiente, a unos niveles sonoros como los descritos reviste una entidad tal que no puede sino reputarse atentatoria contra su derecho al respeto de su vida privada y familiar y a la intimidad e inviolabilidad del domicilio". També en aquest l'Ajuntament de València al·legà que l'ordenança municipal permetia eximir les falles del compliment dels nivells acústics màxims, però la sentència desestima aquesta al·legació, perquè, a banda que l'Ajuntament no va fer ús d'aquesta facultat, "en cualquier caso [...] en modo alguno podría haber efectuado una excepción que permitiese a la falla incumplir los niveles de ruido en un grado tal que produjera inmisiones sonoras en el domicilio [...] vulneradoras de sus derechos fundamentales a la intimidad personal y familiar y la inviolabilidad domiciliaria".
} 
fonamentals com el dret a la intimitat, i, per tant, una de les vies possibles de reacció és la tutela de drets fonamentals.

En l'àmbit de les relacions de veïnatge, cal partir del concepte d'immissió, amb origen ja en la jurisprudència romana i elaborat per la doctrina alemanya de finals del segle XIX. La Sentència del Tribunal Superior de Justícia de Catalunya de 19 de març de 2001 (n. 11/2001, rec. 65/2000, ponent Ponç Feliu Llansá) acull la definició d'immissió de la seva anterior Sentència de 26 març 1994, com a ingerència físicament apreciable en el predi veí de substàncies, partícules o ones, que es propaguen sense intervenció de la voluntat humana, sinó com a conseqüència de l'actuació de principis físics, ja sigui per mitjà de l'aire — soroll—, del sòl o les parets — vibracions—, que tenen el seu origen en l'activitat del propietari o del posseïdor de l'immoble com a conseqüència del gaudiment de la finca, i que s'interfereixen en el gaudi pacífic i útil del dret de propietat o de possessió d'un predi veí que no és absolutament necessari que sigui limítrof.

La jurisprudència espanyola, davant d'un codi civil concebut per a una societat rural molt diferent de la nostra, acostuma a partir de la prohibició de l'abús de dret o del seu exercici antisocial de l'article 7.2, i dels seus articles 590 (construcció de fargues, estables, artefactes que es moguin per vapor o fàbriques a les distàncies prescrites i amb les obres de protecció necessàries), 1902 (responsabilitat civil extracontractual), 1908.2 i 1908.4 (responsabilitat dels propietaris per fums excessius i nocius i per emissions de clavegueres o dipòsits de matèries infeccioses construïts sense les precaucions adequades), amb una interpretació actualitzadora (article 3.1) i analògica (article 4.1) que permet la inclusió en aquests preceptes dels sorolls perjudicials emesos per qualsevol màquina industrial, instrument o aparell.

Cal assenyalar que, d'acord amb la jurisprudència, en l'ordre civil no es tracta tant de determinar si la normativa administrativa es compleix o no, sinó de si s'ha causat o no una lesió efectiva de drets subjectius individuals. La qualificació civil de les activitats com a molestes, insalubres, incòmodes o perilloses és, doncs, independent de l'abast que tinguin en l'esfera administrativa ${ }^{72}$.

\footnotetext{
${ }^{72}$ Ja l'antiga Sentència del Tribunal Suprem de 22 de desembre de 1972 (n. 599/1972, ponent Federico Rodríguez-Solano y Espín) afirmava "el arrendatario cumplió con las condiciones precisas impuestas para la concesión de la licencia municipal, requisito administrativo que, como dicen las sentencias de esta Sala de 30 de abril de 1966 y 23 de septiembre de 1969, no condiciona los derechos civiles, emanados de las Leyes de esta índole". En aquesta mateixa línia, la més recent Sentència del Tribunal Suprem de 26 de novembre de 2010 (n. 739/2010, rec. 901/2007, ponent Encarnación Roca Trías), en relació amb les immissions de soroll, pols i llum d'una fàbrica, recorda, amb esment de diversa jurisprudència, que
} 
"Como ha venido afirmando la jurisprudencia de esta Sala desde antiguo, la circunstancia de la remisión a las normas administrativas efectuada en el art. $590 \mathrm{CC}$ no implica que se produzca una «huida» al derecho administrativo de toda la materia de las relaciones de vecindad por implicar la falta de competencia de la jurisdicción civil". Comenta aquesta sentència PARRA LUCAN, M. A., "Jurisprudencia civil: La tutela civil frente a las inmisiones ilegítimas y la protección del dominio público natural", en Observatorio de políticas ambientales, 2011, pp. 289-312. També es pot esmentar la Sentència de l'Audiència Provincial de la Corunya de 19 de juny de 2012 (Secció 5a, n. 339/2012, rec. 438/2011, ponent Julio J. Tasende Calvo), segons la qual "una cosa es la licencia y control de las Administraciones públicas sobre determinados elementos o instalaciones peligrosas para la salud y la seguridad de las personas o para la integridad de sus bienes, y otra el derecho que a toda persona asiste para evitar las inmisiones nocivas procedentes de dichos elementos y obtener el resarcimiento de las consecuencias dañosas que produzcan tales inmisiones, de acuerdo con los citados arts. 590 y 1908 del $\mathrm{CC}$, sin que la existencia de una autorización administrativa de la actividad causante de la inmisión, o la observancia de las normas reglamentarias que la regulan, impida la exigencia de responsabilidad con arreglo a estos preceptos (SSTS 9 febrero 1971, 12 diciembre 1980, 3 diciembre 1987, 16 enero 1989, 30 mayo 1997 y 31 mayo 2007)". També es pot fer referència a la Sentència de l'Audiència Provincial de Balears de 19 de setembre de 2012 (Secció 5a, n. 402/2012, rec. 222/2012, ponent Mateo Ramón Homar), la qual afirma que "el cumplimiento de las formalidades administrativas para la instalación de un negocio o industria no afecta a las consecuencias del mismo en el orden civil, ni condiciona los derechos de esta índole reconocidos en las leyes". La Sala afegeix, amb esment de nombrosa jurisprudència, que no són obstacle a la tutela civil contra el soroll, ni la regulació administrativa de l'activitat "porque hay que distinguir lo relativo a la tutela preventiva de los intereses generales o públicos, de inequívoca naturaleza administrativa, de lo que atañe a la propiedad e intereses privados y a su protección, de incuestionable carácter civil"; ni la remissió de les normes civils de veïnatge a la normativa administrativa, "porque la reintegración de aquéllas no sustrae al Derecho civil las relaciones que disciplinan, ni traslada sin más el conocimiento y la resolución de sus conflictos a la Administración y su jurisdicción revisora"; ni l'exercici de l'activitat amb la preceptiva llicència administrativa "porque dado su alcance limitado a las relaciones entre la Administración concedente y el sujeto a quien se refiere, y su neutralidad con respecto a los derechos privados de terceros, la actividad emprendida y ejercida con la oportuna licencia puede ser impedida por los tribunales del orden civil a instancia de los particulares cuyos derechos lleguen a verse lesionados por ella"; ni el desenvolupament de l'activitat amb compliment de la normativa administrativa "porque su acatamiento y cumplimiento no colocan al obligado al abrigo de la correspondiente acción civil que los perjudicados o afectados puedan ejercitar en defensa de sus derechos subjetivos lesionados [...], ni alteran la responsabilidad de quienes las cumplen cuando a las medidas reglamentarias se revelan insuficientes para evitar eventos lesivos". Així mateix, la Sentència de l'Audiència Provincial de València, de 24 de gener de 2014 (Secció 8a, n. 21/2014, rec. 237/2013, ponent Eugenio Sánchez Alcaraz), dictada en relació amb les molèsties generades per un pub amb llicència, i que confirma l'obligació de cessament de l'activitat, afirma, esmentant la STS de 29 d'abril de 2003, que "los ruidos desaforados y persistentes, aunque estos procedan en principio, del desarrollo de actividades lícitas, dejan de serlo, cuando se traspasan determinados límites", y ello aunque la actividad emisora del ruido no sólo sea lícita sino que incluso cumpla con las normas reglamentarias". La Sala considera que sempre que les immissions excedeixen del límit normal de tolerància existeix un manifest abús de dret, i afirma que "Lo importante es comprobar que la Ley prohíbe todo lo que entrañe molestia grave, sin sujetarse a los límites del Reglamento de índole estrictamente administrativa y destinada a marcar las pautas de la actuación de los organismos públicos, puesto que lo que se reconoce al ciudadano es el derecho a vivir sin ser perturbado por la acción de otros, no simplemente a exigirles el cumplimiento estricto de las disposiciones reglamentarias". En aquests termes es pronuncia també la més recent Sentència de la mateixa l'Audiència Provincial de València de 5 d'octubre de 2015 (Secció 8a, n. 255/2015, rec. 161/2015). També la Sentència de l'Audiència Provincial de Madrid de 4 de juliol de 2014 (Secció 25a, n. 268/2014, rec. 9/2014, ponent Fernando Delgado Rodríguez) reitera les afirmacions ja reproduïdes, i afegeix que "la autorización administrativa de una industria no es de suyo bastante para entender que fue otorgada ponderando un justo y equitativo equilibrio entre el interés general y los derechos de los afectados [...] Después, la STS de 28 de enero de 2004 [...] consideraría que no era misión del Derecho civil la protección del medio ambiente en abstracto pero sí la «protección específica a derechos subjetivos patrimoniales» frente a agresiones de carácter medioambiental; y en fin, reiteraría una vez más tanto la doctrina de que «el cumplimiento de normativa reglamentaria no impide la apreciación de responsabilidad cuando concurre la realidad del daño causado por la persona física o jurídica» como la relativa al carácter objetivo de la responsabilidad contemplada en el artículo 1908 del Código Civil". Certament, la concepció del dret administratiu que reflecteixen algunes de les sentències esmentades és discutible, 
Així, la protecció civil davant la contaminació acústica permet a la part perjudicada exercitar la pretensió de condemna al cessament de l'activitat i a la indemnització dels perjudicis causats per aquesta activitat ${ }^{73}$, inclòs el dany moral ${ }^{74}$, amb independència que l'activitat disposi dels permisos administratius en regla o compleixi els límits acústics establerts administrativament. A més, és d'aplicació la doctrina jurisprudencial de la presumpció iuris tantum de culpa de l'agent, sempre que s'acrediti la pertorbació, amb inversió de la càrrega de la prova, amb una tendència a l'objectivació de la

sobretot perquè l'Administració, amb la seva actuació, ha de servir amb objectivitat els interessos generals (art. 103.1 de la Constitució, 3.1 de la Llei 30/1992, etc.), i entre aquests interessos generals es troben també, i molt especialment, els dels particulars que poden resultar afectats per l'activitat sotmesa a llicència. A més, l'actuació de l'Administració no es limita al mer atorgament de la llicència, sinó que també s'estén a l'exercici de les potestats control, inspecció i sanció al llarg de tot el desenvolupament de l'activitat. Com bé afirma la Sentència de la Sentència del Tribunal Superior de Justícia de Catalunya de 3 d'octubre de 2002 (Sala Civil, n. 28/2002, rec. 27/2002, ponent Nuria Bassols Muntada), "el que ha de quedar clar és que en l'àmbit de les activitats molestes, contràries a la salut o perilloses, encara que s'hagi atorgat llicència això no suposa que s'entri a partir d'aquell moment en una situació petrificada i inamovible, sinó que en el cas que s'observi per part de l'Administració l'incompliment de les condicions exigides, o, en el seu cas, deficiències en el compliment, pot adoptar mesures correctores, inclosa la retirada de la llicència i clausura de l'activitat. Queda doncs en mans de l'Administració la decisió de decretar la clausura de l'activitat quan hi hagi incompliment dels requisits tècnics exigits per les normes administratives". Així mateix, en la mateixa jurisdicció contenciosa, la Sentència del Tribunal Superior d'Andalusia (Granada) de 23 de novembre de 2015 (Seccióla, n. 2072/2015, rec. 603/2015), recorda, amb relació als sorolls generats per un establiment amb llicència municipal, que aquesta llicència "no se limita al mero control y autorización de las instal·laciones [...], sino que se proyecta hacia el futuro para condicionar de modo continuado el funcionamiento de la actividad que se autoriza; constituye, por tanto, una autorización operativa, cuya virtualidad no se agota en el control preventivo que la Administración efectúa en el acto de licencia; el control administrativo se extiende [...] a lo largo de todo el desarrollo de la actividad, [...] en las condiciones precisas de tranquilidad, seguridad y salubridad". Per tant, "la actividad está siempre sometida a la condición implícita de tener que ajustarse a las exigencias del interés público, lo que habilita a la Administración para intervenir, incluso de oficio, imponiendo las medidas de corrección y adaptación que resulten necesarias $\mathrm{y}$, en último término, proceder a la revocación de la autorización [...] Las medidas correctoras pueden ser exigidas en cualquier tiempo, ya que, como se indica en la sentencia del Tribunal Supremo de 6 de noviembre de 1996 , «como el peligro no prescribe», la Administración puede exigir su puesta en práctica, para la seguridad de personas y cosas (STS de 6 de noviembre de 1996)".

${ }^{73}$ La Sentència de l'Audiència Provincial de la Corunya de 19 de juny de 2012, abans esmentada, afirma que "de estas situaciones nace, en favor del propietario perjudicado o sujeto a riesgo, el doble derecho de hacer cesar el daño o peligro, al amparo del art. 590 del CC (SSTS 12 diciembre 1980, 16 enero 1989 y 30 noviembre 2006), y de obtener una indemnización o resarcimiento por el perjuicio patrimonial causado, conforme al art. 1908, que contempla una forma de responsabilidad objetiva (SSTS 14 mayo 1963, 15 marzo 1993 y 17 marzo 1998) y cuya aplicación, en relación con el art. 1902 del CC, se extiende a las inmisiones intolerables y a las agresiones del medio ambiente (SSTS 12 diciembre 1980, 3 septiembre 1992, 15 marzo 1993, 29 abril 2003, 28 enero 2004 y 14 marzo 2005)".

${ }^{74}$ Pel que fa a la distinció entre el dany a la salut i dany moral, es pot esmentar la Sentència de l'Audiència Provincial d'Alacant, de 7 d'abril de 2003 (Secció 6a, n. 182/2003, rec. 623/2002, ponent José María Rives Seva), segons la qual "es esa molestia y desazón que produce todo ruido lo que hace que el mismo origine un perjuicio, que puede ser material, en cuanto incide sobre el propio componente corporal o psíquico de quién lo padece, o bien de naturaleza moral que es también indemnizable". 
responsabilitat (tot i que cal acreditar en tot cas el nexe causal entre les immissions i els danys causats) ${ }^{75}$.

Pel que fa a la intensitat de la ingerència, ja segons l'antiga Sentència del Tribunal Suprem de 22 de desembre de 1972 (n. 599/1972, ponent Federico Rodríguez-Solano y Espín), dictada en relació amb les molèsties causades per una sala de festes, han de qualificar-se com a notòriament incòmodes i molestes activitats sorolloses perfectament audibles durant la nit, sense que sigui necessari que la incomoditat sigui insofrible o intolerable, i n'hi ha prou que resulti desagradable per als ocupants de la finca encara que sigui suportable ${ }^{76}$.

En síntesi, la protecció civil contra el soroll es fonamenta en la regla bàsica segons la qual la propietat no pot arribar més enllà d'allò que el respecte al veí determina (entre les més recents, hi ha les sentències de l'Audiència Provincial de València de 24 de gener de 2014 —Secció 8a, n. 21/2014, rec. 237/2013, ponent Eugenio Sánchez Alcaraz-o de 5 d'octubre de 2015 — Secció 8a, n. 255/2015, rec. 161/2015) ${ }^{77}$.

Aquesta jurisprudència obre la porta a l'arbitri de l'òrgan jurisdiccional, en la mesura que és aquest ens el que pot decidir el tancament d'activitats, si entén que les immissions generades superen el límit d'allò que consideri com a admissible, encara que compleixin els paràmetres objectius establerts en la normativa administrativa pel que fa a sorolls i disposin de totes les autoritzacions requerides. Aquesta discrecionalitat judicial resulta difícilment conciliable amb el principi de seguretat jurídica, i, a més, pot portar a solucions que no siguin ni les més justes ni les més adequades socialment ${ }^{78}$.

\footnotetext{
${ }^{75}$ En aquest sentit, la Sentència de l'Audiència Provincial de Madrid de 4 de juliol de 2014 o de l'Audiència Provincial de la Corunya de 19 de juny de 2014, abans esmentades, que es refereixen al caràcter objectiu d'aquesta responsabilitat.

${ }^{76}$ La sentència considera "como notoria y ostensiblemente incómodas y molestas, aquellas actividades que, como las aquí discutidas, originan ruidos o vibraciones perfectamente audibles, a altas horas de la noche por los diversos vecinos que residen en el inmueble, donde aquéllas se ejercen [...], sin que a ello pueda oponerse con éxito [...] que para que tal efecto se produzca es indispensable que la incomodidad a que se ha hecho referencia sea insufrible o intolerable, porque, como expresan las sentencias de 5 de mayo de 1949, 10 de junio de 1950 y 6 de mayo de 1957, es suficiente [...] que la industria resulte desagradable para los ocupantes de la,finca aunque les sea soportable y posible su permanencia en ella".

77 També en aquest sentit, la Sentència del Tribunal Suprem de 26 de novembre de 2010 (n. 739/2010, rec. 901/2007, ponent Encarnación Roca Trías), esmentada més endavant.

${ }^{78}$ Cal no oblidar, a més, la dificultat que pot suposar, en aquest tema, l'apreciació subjectiva del soroll, que fa que, allò que per una persona pot resultar molest, per una altra resulti indiferent, o fins $i$ tot agradable.
} 
En canvi, el Llibre cinquè del Codi civil de Catalunya, aprovat per Llei 5/2006, de 10 de maig, atent també els altres interessos implicats, es remet als valors límit establerts a la normativa administrativa ${ }^{79}$ i no permet exigir el tancament d'activitats autoritzades administrativament ${ }^{80}$. En aquest sentit, per exemple, la Sentència de l'Audiència

\footnotetext{
${ }^{79}$ No obstant això, cal també no oblidar que el mateix article 590 del Codi civil espanyol també es remet als reglaments. La ja esmentada Sentència del Tribunal Suprem de 26 de novembre de 2010 (n. 739/2010, rec. 901/2007, ponent Encarnación Roca Trías), després de recordar que "la propiedad no puede llegar más allà de lo que el respeto al vecino determina", desestima l'al·legació que d'acord amb l'article 590 del Codi civil només es pot demanar que es compleixin els reglaments, però no l'eliminació total de les molèsties, i afirma que "cuando el art. $590 \mathrm{CC}$ remite a los reglamentos reguladores de la actividad que está causando un daño a las propiedades vecinas, no está transformando la norma civil en norma administrativa, sino integrando en el ordenamiento civil los criterios para la calificación de la actividad que genera las inmisiones". Comenta aquesta sentència PARRA LUCAN, M. A., "Jurisprudencia civil: La tutela civil frente a las inmisiones ilegítimas y la protección del dominio público natural", en Observatorio de políticas ambientales, 2011, pp. 289-312.

${ }^{80}$ L'article 546-13 (titulat "Immissions il-legítimes") disposa que les immissions, entre altres elements, de soroll, produïdes per actes il-legítims dels veïns i que causen danys a la finca o a les persones que hi habiten, són prohibides i generen responsabilitat pel dany causat. L'article 546-14 (titulat "Immissions legítimes") afegeix que:
}

1. Els propietaris d'una finca han de tolerar les immissions provinents d'una finca veïna que són innòcues o que causen perjudicis no substancials. En general, es consideren perjudicis substancials els que superen els valors límit o indicatius que estableixen les Lleis o els reglaments (en conseqüència, caldrà acudir a la normativa administrativa en matèria de soroll, que proporciona paràmetres objectius).

2. Els propietaris d'una finca han de tolerar les immissions que produeixin perjudicis substancials si són conseqüència de l'ús normal de la finca veïna, segons la normativa, i si fer-les cessar comporta una despesa desproporcionada econòmicament.

3. En el cas a què fa referència l'apartat 2, els propietaris afectats tenen dret a rebre una indemnització pels danys produïts en el passat $i$ una compensació econòmica, fixada de comú acord o judicialment, pels que es puguin produir en el futur si aquestes immissions afecten exageradament el producte de la finca o l'ús normal d'aquesta, segons el costum local (s'intenta, per tant, arribar a un just equilibri entre els diferents interessos contraposats, en la línia de la jurisprudència del Tribunal Europeu de Drets Humans, i sense imposar la cessació de l'activitat).

4. Segons la naturalesa de la immissió a què fa referència l'apartat 2, els propietaris afectats poden exigir, a més del que estableix l'apartat 3 , que aquesta es faci en el dia i el moment menys perjudicials i poden adoptar les mesures procedents per a atenuar els danys a càrrec dels propietaris veïns.

5. Les immissions substancials que provenen d'instal•lacions autoritzades administrativament faculten els propietaris veïns afectats a sol•licitar l'adopció de les mesures tècnicament possibles i econòmicament raonables per a evitar les conseqüències danyoses i a sol•licitar la indemnització pels danys produïts. Si les conseqüències no es poden evitar d'aquesta manera, els propietaris tenen dret a una compensació econòmica, fixada de comú acord o judicialment, pels danys que es puguin produir en el futur (com hem dit, s'intenta un equilibri just entre els diferents interessos en joc, sense imposar la cessació de l'activitat).

6. Cap propietari o propietària no està obligat a tolerar immissions dirigides especialment $\mathrm{o}$ artificialment vers la seva propietat.

7. La pretensió per a reclamar la indemnització pels danys i perjudicis o la compensació econòmica a què fan referència els apartats 3 i 5 prescriu al cap de tres anys, comptats a partir del moment en què els propietaris tinguin coneixement de les immissions. 
Provincial de Barcelona de 15 de març de 2011 (Secció 4a, n. 121/2011, rec. 291/2010, ponent Mireia Rios Enrich) desestima la petició de cessació de l'activitat, ja que es tracta d'una instal-lació autoritzada administrativament, i declara l'obligació de la demandada de costejar les mesures tècnicament possibles i econòmicament viables per disminuir els efectes de les immissions ${ }^{81}$. També és interessant la recent Sentència de 1'Audiència Provincial de Barcelona de 5 d'octubre de 2015, en relació amb els sorolls generats per l'aire condicionat, i en la qual, si bé es constata que se superen els límits establerts en la normativa administrativa, no es considera que es causi un perjudici substancial $^{82}$.

Aquesta regulació presenta els avantatges propis de la seguretat jurídica, cerca la solució més justa i menys costosa en cada cas i impedeix l'expulsió del territori d'activitats, industrials, o d'una altra mena, que s'han vist engolides pel creixement dels nuclis urbans. Per contra, també implica atribuir una notable importància als complexos informes sonomètrics, que hauran d'aportar i sufragar els afectats i que hauran de complir escrupolosament tots els requisits tècnics per evitar-ne la impugnació ${ }^{83}$.

En l'àmbit de la propietat horitzontal, l'article 7.2 de la Llei 49/1960, de 21 de juliol, de propietat horitzontal, permet l'exercici d'una acció de cessació de l'activitat molesta i d'indemnització dels danys ${ }^{84}$. A Catalunya, cal esmentar l'article 553-40 (titulat

\footnotetext{
${ }^{81} \mathrm{La}$ sentència afegeix que "Si aún así las consecuencias no pudieran evitarse, la propietària podrà reclamar la indemnización correspondiente por los daños y perjucios causados". Aquesta sentència esmenta la Sentència del Tribunal Superior de Justícia de Catalunya de 3 d'octubre de 2002, abans anomenada, segons la qual "no hi ha cap raó per excloure les pertorbacions produïdes per instal·lacions autoritzades administrativament de la indemnització de danys i perjudicis [...] L'única especialitat de les immissions produïdes per instal lacions autoritzades administrativament en front a les que no gaudeixen (o no necessiten) autorització administrativa és que no es pot exigir als seus titulars el tancament de la instal·lació o mesures que no siguin tècnicament possibles i econòmicament raonables per tal d'evitar les immissions".

${ }^{82}$ Per això, es considera que no existeix una intromissió il·legítima, tot i que la sentència afegeix que "Ello es sin perjuicio, obviamente, de que la obligación de respetar los límites de inmisión acústica es permanente, por lo que el hecho de que se desestime ahora la demanda no exonera a la demandada de la obligación de respetar los límites de inmisión. La ley y el reglamento sobre ruidos son de obligado cumplimiento en todo tiempo".

${ }^{83}$ CALVO RETUERTO, J.; RUÍZ MARTÍNEZ, V., "Las inmisiones de ruidos en el Derecho Civil Catalán", en Actualidad Jurídica (Uría \& Menéndez), núm. 22, abril 2009. Recuperat el 5 de maig de 2015 de http://www.uria.com/documentos/publicaciones/2201/documento/articuloUM.pdf?id=3091. Aquest problema de la validesa i correcció dels mesuraments també es plantejà en la ja esmentada Sentència de l'Audiència Provincial de Barcelona de 5 d'octubre de 2015.

${ }^{84}$ L'article 7.2 prohibeix al propietari i a l'ocupant exercir-hi, en el pis, local o resta de l'immoble, activitats prohibides en els estatuts que perjudiquin la finca o que contravinguin les disposicions generals sobre activitats molestes, insalubres, nocives, perilloses o il·lícites, i regula el requeriment del president $\mathrm{i}$ l'acció de cessació. Com a exemples de sentències que imposen el cessament, es pot fer referència des de la ja esmentada Sentència del Tribunal Suprem de 22 de desembre de 1972, a la Sentència de l'Audiència
} 
"Prohibicions i restriccions d'ús dels elements privatius i comuns") del Llibre cinquè del Codi civil de Catalunya ${ }^{85}$.

Però cal no oblidar també la possibilitat que la comunitat de propietaris acabi essent condemnada per les molèsties generades pels sorolls. En aquest sentit, es pot esmentar la Sentència de 1'Audiència Provincial de Madrid de 5 de març de 2015 (Secció, 21a, n. 63/2015, rec. 45/2014, ponent Virginia Villanueva Cabrer), que condemna la comunitat a efectuar les obres necessàries per evitar que els sorolls d'un ascensor, superiors als màxims fixats per l'ordenança municipal d'acord amb els informes pericials, es transmetin a l'habitatge de la part demandant, d'acord amb els articles 10.1 de la Llei de propietat horitzontal (que imposa a la comunitat l'obligació de dur a terme les obres necessàries per a l'adequat sosteniment i conservació de l'immoble) i 1902 del Codi civil, i afirma que la comunitat té l'obligació d'efectuar les reparacions necessàries per evitar que l'existència de defectes en els elements comuns impedeixin el gaudi dels elements privatius ${ }^{86}$.

Quant a l'aplicació de la Llei orgànica 1/82, de 5 de maig, de protecció civil del dret a l'honor, a la intimitat personal i familiar i a la pròpia imatge, ja la Sentència del Tribunal Suprem de 29 d'abril de 2003 establí una doctrina clara, que es reitera constantment pels tribunals ${ }^{87}$, que afirma que intentar limitar l'article 7 de la Llei

Provincial de Navarra de 4 de novembre de 2014 (Secció 3a, n. 302/2014, rec. 351/2014, ponent María Belén Pérez-Flecha Díaz), que imposa el cessament de les activitats d'oci a les quals destinaven uns locals comercials els seus propietaris. La Llei 29/1994, de 24 de novembre, d'arrendaments urbans, també permet a l'arrendador resoldre el contracte quan en l'habitatge hi tinguin lloc activitats molestes, insalubres, nocives, perilloses o il·lícites (art. $27.2 \mathrm{e}$ ).

${ }^{85}$ Segons aquesta norma, els propietaris i ocupants no poden fer activitats contràries a la convivència normal en la comunitat o que els estatuts o la normativa urbanística o la llei exclouen o prohibeixen expressament (apartat 1), i afegeix que la presidència, per iniciativa pròpia o a petició d'una quarta part dels propietaris, ha de requerir fefaentment el cessament, i si es persisteix, la junta pot interposar l'acció de cessació. Una vegada presentada la demanda, que s'ha d'acompanyar del requeriment $\mathrm{i}$ de la certificació de l'acord de la junta, l'autoritat judicial ha d'adoptar les mesures cautelars convenients, entre les quals, la cessació immediata de l'activitat (apartat 2). Així mateix, la comunitat té dret a la indemnització pels perjudicis que se li causin i, si les activitats prohibides continuen, a instar judicialment la privació de l'ús i el gaudi de l'element privatiu per un període de fins a dos anys i, si escau, l'extinció del contracte d'arrendament o de qualsevol altre que empari als ocupants (apartat 3).

\footnotetext{
${ }^{86}$ Així mateix, d'acord amb l'article 553.44 del Llibre cinquè del Codi civil de Catalunya, la comunitat ha de conservar els elements comuns de l'immoble, de manera que compleixi les condicions estructurals, d'habitabilitat, d'accessibilitat, d'estanquitat i de seguretat necessàries o exigibles segons la normativa vigent $i$ ha de mantenir en funcionament correcte els serveis i les instal-lacions. Els propietaris han d'assumir les obres de conservació i reparació necessàries. Quant a les obligacions de la comunitat de propietaris, també es poden esmentar l'article 28 del model A de l'ordenança tipus elaborada per la Generalitat i l'article 18 del model B.

${ }^{87}$ Per exemple, a les ja esmentades sentències de l'Audiència Provincial de la Corunya de 19 de juny de 2012 o de 1'Audiència Provincial de València de 24 de gener de 2014.
} 
orgànica 1/1982 als supòsits d'escoltes i publicacions de converses privades en el domicili familiar és reduccionista i contrari a la realitat social actual, tot i que el text de la llei no preveu les immissions sonores ${ }^{88}$.

Cal assenyalar que aquesta acció té l'avantatge, respecte a les derivades de la culpa extracontractual, d'un termini de prescripció més ampli, de quatre anys (art. 9.5 de la Llei orgànica 1/1982).

Finalment, cal fer referència al problema de la prova de les immissions i els danys, que, com ja hem dit, és una constant en tots els ordres jurisdiccionals.

En el cas de l'esmentada Sentència de l'Audiència Provincial de València, de 24 de gener de 2014, es plantejà el problema de la prova de les immissions, amb l'existència d'informes pericials contradictoris. Aquest problema també es plantejà en l'assumpte finalment resolt per la Sentència del Tribunal Suprem de 5 de març de 2012, en el qual, si bé el Jutjat considerà les molèsties causes per les pràctiques de piano d'uns veïns una intromissió il·legítima en la intimitat personal i familiar en l'àmbit domiciliari, i condemnà la part demandada que deixés de tocar el piano o bé que adoptés les mesures d'insonorització adequades per evitar les molèsties en l'habitatge de les parts demandants, juntament amb una indemnització, l'Audiència Provincial de València revocà la Sentència, atenent el fet que la càrrega de la prova correspon a les parts demandants i que, en conseqüència, el dubte entre els informes pericials contradictoris s'ha de resoldre en favor de les parts demandades. El Tribunal Suprem estima el recurs

\footnotetext{
${ }^{88}$ La sentència afirma que "el planteamiento que se hace sobre la tipología de las intromisiones ilegítimas pretendiendo implícitamente que se circunscriba a los concretos supuestos del artículo 7 de la L.O. 1/1982, ya fue rechazado por esta Sala (sentencias del Tribunal Supremo de 28 de octubre de 1986, 4 de noviembre de 1996, entre otras) que ante la fuerza expansiva de los derechos fundamentales y, con apoyo en el propio texto normativo, se atiene a la realidad de su vulneración más que a lo medios con que aquella se realice. Ello es particularmente exigible en aquellos derechos fundamentales, como el de la intimidad, cuya noción o determinación conceptual fuera de su vaga definición como, «derecho a ser dejado en paz», equivalente a derecho a la soledad y a la tranquilidad, obliga a caracterizarlos desde la perspectiva de los actos concretos que inciden en su contenido o núcleo esencial. En ese sentido, la protección a la intimidad no queda reducida a la evitación y proscripción de la divulgación de la vida privada o la penetración no autorizada en el ámbito en que se desarrolla la vida privada. Nuevas formas o nuevos procedimientos que alteran gravemente la paz familiar y el entorno en que se desarrolla la vida íntima o privada constituyen manifestaciones de intromisión ilegítima frente a las cuales cabe y es obligada la tutela judicial, como se desprende de la sentencia del Tribunal Constitucional en Pleno de 24 de mayo de 2001 y de la jurisprudencia del T.E.H.D. (sentencias de 21 de febrero de 1990, caso Powell y Rayner; 9 de diciembre de 1994, caso López Ostra)". No obstant això, és clar que 1'article 7 de la Llei no inclou, entre els supòsits d'intromissió il·legíma, el soroll (de fet, els supòsits que esmenta no hi tenen a res veure), i una cosa és interpretar les normes atenent a la realitat social i una altra és actuar com a legislador. A més, l'article 2.2 i l'article 8 de la Llei exclouen l'existència d'intromissió il·legítima en l'àmbit protegit quan estigui expressament autoritzada per 1lei, la qual cosa portaria a excloure els supòsits d'activitats amb llicència o autorització administrativa, tot i que la jurisprudència no ho vegi així (Sentència del Tribunal Suprem de 29 de maig de 2001).
} 
contra la Sentència de l'Audiència Provincial, entenent que no es pot exigir una prova que vagi més enllà de qualsevol possibilitat raonable, i més quan es lesiona un dret fonamental ${ }^{89}$.

També resulta interessant assenyalar, pel que fa a la prova dels danys morals patits per les immissions acústiques, el règim especialment favorable a la part demandant que configura la jurisprudència civil. En són bons exemples, a més de la ja esmentada Sentència l'Audiència Provincial d'Alacant de 7 d'abril de $2003^{90}$, les sentències de 1'Audiència Provincial de Biscaia de 7 de desembre de 2010 (Secció 5a, n. 532/2010, rec. 232/2010, ponent Elisabeth Huerta Sánchez) ${ }^{91}$, o també l'esmentada Sentència del Tribunal Suprem de 26 de novembre de 2010 (n. 739/2010, rec. 901/2007, ponent Encarnación Roca Trías) ${ }^{92}$, o de l'Audiència Provincial de Madrid de 4 de juliol de 2014 (Secció 25a, n. 268/2014, rec. 9/2014, ponent Fernando Delgado Rodríguez) ${ }^{93}$.

\footnotetext{
${ }^{89}$ El Tribunal Suprem afirma que "no se alcanza a comprender qué otra prueba cabía exigir a la parte demandante para acreditar los hechos constitutivos de su pretensión y, sin embargo, a la parte demandada sí le era exigible, cuando menos, un informe contradictorio de las mediciones contenidas en el informe acompañado con la demanda, no un crítica de este mismo informe que, sobre muy pobremente fundada, estaba en flagrante contradicción con las actuaciones documentales de la Policía Local y con el propio acuerdo de la comunidad de propietarios" (FJ 2n, 4a), i afegeix que "si conforme al apdo. 7 del art. 217 LEC no puede exigirse a ningún litigante una prueba que vaya más allá de cualquier posibilidad razonable, menos aún podrá exigírsele cuando con ello se menoscabe o dificulte la tutela de un derecho fundamental hasta el punto de dejarle indefenso".
}

${ }^{90}$ Segons la qual, "Lo cierto y probado en autos es que con la conducta negativa del demandado se produjo la ilícita inmisión y ello hace en innecesaria la prueba del daño, que se da por sobreentendida".

${ }^{91}$ La qual, després d'esmentar l'abundant jurisprudència, tant del Tribunal Suprem com de les audiències provincials, conclou afirmant que "La doctrina jurisprudencial, pues, declara que, ante la realidad y persistencia de una inmisión de ruido por encima de los límites de obligada tolerancia, la certeza del daño moral sufrido por quien se ha visto compelido a soportarla no requiere una prueba adicional de las reacciones, sentimientos y sensaciones que han acompañado a su padecimiento. A diferencia de los procedentes de otras causas, los daños morales derivados del ruido hallan en la constatación de las propias inmisiones y de sus intolerables molestias la justificación de su misma realidad, lo que no es sino aplicación a estos casos de la doctrina de la «iure ipsa loquitur»".

${ }^{92}$ Que confirma la condemna a indemnitzar els actors en tots els perjudicis materials i morals que els siguin causats al llarg del temps, des de la interposició de la demanda origen del plet fins a la total execució i verificació de totes les mesures correctores, sense excepció, necessàries per eliminar definitivament qualsevol perjudici futur, que caldrà fixar quantitativament en execució de sentència. També respecte als danys morals, la sentència els considera provats, i també admet que la seva quantia sigui igual per a cadascun dels demandants ("debe recordarse aquí que la cantidad fijada en la sentencia no es revisable en casación, salvo casos excepcionales, excepcionalidad que no concurren en el presente litigio". PARRA LUCAN, M.A., "Jurisprudencia civil: La tutela civil frente a las inmisiones ilegítimas y la protección del dominio público natural”, en Observatorio de políticas ambientales, 2011, pp. 289-312.

${ }^{93}$ La sentència afirma que "Para el Tribunal Supremo, en las inmisiones sonoras no se pueden considerar totalmente faltos de prueba los daños morales [...] Y es que, según la línea jurisprudencial seguida, entre otras, en SSTS de 22 de mayo y 3 de noviembre de 1995, se puede englobar en el concepto de daño moral toda la gama de sufrimientos y dolores físicos o psíquicos que haya padecido la víctima a consecuencia de hecho ilícito y, como se razonaba en la de 14 de diciembre de 1996, «el sufrimiento físico o espiritual» debe originar también una reparación «que proporcione en la medida de lo posible una satisfacción compensatoria al sufrimiento causado»". 
Resulten també interessants l'esmentada Sentència de l'Audiència Provincial de València de 5 d'octubre de 2015 (Secció 8a, n. 255/2015, rec. 161/2015), que, en un cas de pertorbacions sonores patides en el despatx d'un advocat, confirma la indemnització concedida, atès que al despatx no s'hi pernocta $\mathrm{i}$ als matins els advocats són a les seus judicials $^{94}$, o la Sentència de l'Audiència Provincial de Madrid de 14 d'octubre de 2015 (Secció 20a, n. 362/2015, rec. 623/2014), que qualifica les immissions acústiques en un habitatge com a vici ocult, i imposa a la constructora la responsabilitat solidària juntament amb l'empresa causant dels sorolls ${ }^{95}$.

\section{LA PROTECCIÓ EN L’ÀMBIT PENAL}

El medi ambient és un dels pocs béns jurídics que la Constitució, en l'article 45, esmenta expressament com a objecte de protecció o tutela penal ${ }^{96}$, tot i que la protecció penal contra el soroll no caldria si l'Administració actués sempre diligentment contra els causants de les pertorbacions sonores.

L'article 325 del Codi penal (modificat per la Llei orgànica 5/2010, de 22 de juny, amb què augmenta la seva penalitat, de conformitat amb la Directiva 2008/99/CE de 19 de novembre, relativa a la protecció del medi ambient mitjançant el dret penal, i novament per la Llei orgànica 1/2015, de 30 març, amb què introdueix una nova redacció en vigor a partir de l'1 de juliol del $2015^{97}$ ) conté el tipus bàsic pel que fa a contaminació, i estableix que:

\footnotetext{
${ }^{94}$ La part demandant reclamava 26.712 euros per danys i perjudicis, quantia calculada havent multiplicat el preu del lloguer en la zona per 22 mensualitats (que és el temps durant el qual es prolongaren les pertorbacions). La sentència confirma la indemnització concedida en primera instància de 8.013,60 euros, perquè el despatx només estava ocupat durant l'horari laboral $i$, a més, perquè és públic i notori que els advocats durant els matins acudeixen a les seus judicials, facultat moderadora de la responsabilitat emparada en l'article 1.103 del Codi civil. La sentència també recorda que l'apreciació del dany que cal indemnitzar és una qüestió de fet que correspon al jutge d'instància.

${ }^{95}$ La sentència considera també que les inmisions acústiques constitueixen danys continuats $\mathrm{i}$ de producció succesiva, de manera que la prescripció no s'inicia fins a la producció del resultat definitiu.

${ }^{96}$ Així ho expressa la Sentència del Tribunal Suprem de 24 de febrer de 2003 (Sala 2a, n. 52/2003, rec. 312/2001, ponent Carlos Granados Pérez).

${ }^{97}$ El preàmbul de la Llei orgànica $1 / 2015$ no conté cap referència als motius de les modificacions introduïdes al capítol III del títol XVI. Quant a l'article 325, l'esmena núm. 856 del Grup Parlamentari Popular assenyalava la necessitat d'adaptar el precepte a la Directiva 2009/123/CE, del Parlament europeu i del Consell, de 21 d'octubre, en relació amb la contaminació de vaixells. No obstant això, la reforma va més enllà, ja que inclou un nou delicte a l'apartat $1, \mathrm{i}$ tipifica infraccions menys greus que les de l'apartat 2, que recull amb modificacions substancials el que fins ara havia estat el tipus bàsic. QUINTERO OLIVARES, G., i altres, Comentario a la reforma penal de 2015, 1a edició, Aranzadi, Pamplona, 2015.
} 
1. S'ha de castigar amb les penes de presó de sis mesos a dos anys, multa de deu a catorze mesos i inhabilitació especial per a la professió o ofici per un temps d'un a dos anys el qui, contravenint les lleis o altres disposicions de caràcter general protectores del medi ambient, provoqui o realitzi directament o indirectament emissions, abocaments, radiacions, extraccions o excavacions, aterraments, sorolls, vibracions, injeccions o dipòsits, a l'atmosfera, el sòl, el subsòl o les aigües terrestres, subterrànies o marítimes, inclosa l'alta mar, amb incidència fins i tot en els espais transfronterers, així com les captacions d'aigües que, per si mateixos o conjuntament amb altres, causi o pugui causar danys substancials a la qualitat de l'aire, del sòl o de les aigües, o a animals o plantes ${ }^{98}$.

2. Si les conductes anteriors, per si mateixes o conjuntament amb altres, poden perjudicar greument l'equilibri dels sistemes naturals, s'ha d'imposar una pena de presó de dos a cinc anys, multa de vuit a vint-i-quatre mesos i inhabilitació especial per a la professió o ofici per un temps d'un a tres anys.

Si s'ha creat un risc de perjudici greu per a la salut de les persones, s'ha d'imposar la pena de presó en la meitat superior, i es pot arribar fins a la superior en grau ${ }^{99}$.

Des de la primera sentència per contaminació acústica (de l'Audiència Provincial de Palència, de 9 de novembre de $2000^{100}$, tot i que el delicte ja estava tipificat des de

\footnotetext{
${ }^{98}$ En l'obra a la qual s'ha fet referència en la nota anterior, es critica la protecció autònoma d'animals i plantes o l'equiparació que efectua el precepte entre la mera causació d'un perill de lesió i l'efectiva lesió (així, per exemple, es pot arribar a castigar l'emissió de sorolls que podrien causar un dany substancial, per exemple, a aus migratòries).

${ }^{99}$ En l'obra abans esmentada també es critica que aquest últim incís referent a risc greu de perjudici per a la salut sembla limitat a les conductes de l'apartat 2 , tot i que la causació de danys substancials a l'aire, al sol o a les aigües pot posar en perill la salut de les persones.
}

D'altra banda, i pel que fa a la resta de preceptes, l'article 326 bis, que novament iguala la pena del delicte de perill i del delicte de resultat, castiga amb les penes de l'article 325, en els seus supòsits respectius, els qui, contravenint les lleis o altres disposicions de caràcter general, portin a terme l'explotació d'instal'lacions en les quals es dugui a terme una activitat perillosa de manera que causin o puguin causar danys substancials a la qualitat de l'aire, animals, plantes o mort o lesions greus a les persones, o puguin perjudicar greument l'equilibri dels sistemes naturals. L'article 327 (amb defectuosa redacció, atès que primer es refereix als tres articles anteriors i després només a l'anterior) preveu la pena superior en grau, sens perjudici de les que puguin correspondre d'acord amb altres preceptes del Codi, quan la indústria o activitat funcioni clandestinament, sense haver obtingut la preceptiva autorització o aprovació administrativa de les seves instal-lacions; s'hagin desobeït les ordres expresses de l'autoritat administrativa de correcció o suspensió de les activitats; s'hagi falsejat o ocultat informació sobre els aspectes ambientals; s'hagi obstaculitzat l'activitat inspectora de l'Administració, o s'hagi produit un risc de deteriorament irreversible o catastròfic. L'article 328 es refereix a les penes imposables a les persones jurídiques (multa segons la gravetat del delicte, i possibilitat d'imposar les penes de l'article 33.7, lletres b) a g), atenint-se a les regles de l'article 66); l'article 329, a la prevaricació ambiental, i l'article 331 tipifica la imprudència greu (preveu la pena inferior en grau, $i$ ha estat criticat perquè no té en compte les conseqüències del delicte i per la dificultat de distingir entre imprudència greu i lleu).

${ }^{100}$ N. 23/2000, rec. 3/2000, ponent Mauricio Bugidos San José. Aquest retard de la jurisprudència penal a condemnar per soroll resulta indicatiu de la dificultat inicial per concebre'l com un problema de prou 
1995, i el soroll també es podia incloure en l'article 346 bis del Codi penal anterior, introduït per LO 8/1983), la jurisprudència ha anat perfilant els elements fonamentals d'aquest delicte. S'acostumen a assenyalar com a tals:

1. En primer lloc, un requisit objectiu o descriptiu: la causació de soroll, que, com ja s'ha vist, apareix com un dels elements descriptius del tipus objectiu de l'article 325 del Codi. Com afirma la Sentència de 4 de març de 2015, de l'Audiència Provincial de Burgos (Secció 1a, n. 74/2015, rec. 11/2015, ponent Roger Redondo Argüelles), “se sanciona la realización directa de ruidos en la atmósfera, ruidos que deben entenderse como sonidos emitidos, inarticulados y confusos más o menos fuertes que se propagan por ondas". Aquesta mateixa sentència afegeix que aquest delicte també es pot cometre en comissió per omissió ${ }^{101}$.

La Sentència del Tribunal Suprem de 22 d'abril de 2015 (n. 244/2015, rec. 1574/2014, ponent Joaquín Giménez García), amb esment de la Sentència del Tribunal Suprem 89/2013, d'11 de febrer, i altres, recorda que es tracta d'un delicte que sanciona una conducta global, integrada per una pluralitat i reiteració d'accions, raó per la qual es descarta la continuïtat delictiva.

2. En segon lloc, un element normatiu, que exigeix que la conducta esmentada es dugui a terme contravenint les lleis o altres disposicions de caràcter general protectores del medi ambient. Es tracta, doncs, d'un tipus penal en blanc, que cal integrar amb la corresponent normativa sectorial, incloent, no només normes amb rang de llei, sinó també normes reglamentàries, com les ordenances municipals (sentències del Tribunal Suprem de 5 de novembre de 2009 -n. 1307/2009, rec. 954/2009, ponent Siro Francisco García Pérez-, de 2 de març de 2012 —n. 152/2012, rec. 823/2011, ponent Carlos Granados Pérez-, o de 13 de maig de 2013 —n. 410/2013, rec. 1366/2012,

rellevància per justificar la intervenció del dret penal i del canvi experimentat en la percepció d'aquest problema. En aquest sentit, GARCÍA ÁLVAREZ, G., "La evolución del régimen jurídico del ruido", en Revista de Administración Pública, núm. 186, 2011, pp. 353-386.

101 També es pot cometre directament o indirectament, i és punible a títol de coautor o cooperador necessari qui indueix o contracta un altre per consumar les accions delictives. Els propietaris o directors de l'empresa només responen si tenen coneixement de la infracció normativa. El treballadors que han d'obeir les ordres no són còmplices. VÁZQUEZ IRUZUBIETA, C., Código Penal comentado, 1a edició, Atelier, Barcelona, 2015. Tot i que ja excedeix dels objectius d'aquest article, cal no oblidar també les condemnes per prevaricació per omissió, en cas d'alcaldes que no actuen contra el soroll tot i les reiterades denúncies de les parts afectades (en aquest sentit, l'esmentada Sentència del Tribunal Suprem de 10 de novembre de 2015). 
ponent Andrés Martínez Arrieta—; Sentència del Tribunal Constitucional 128/1998, de 15 de juny) ${ }^{102}$.

3. En tercer lloc, un element subjectiu. En aquest cas, el tipus subjectiu "se integra por el conocimiento del grave riesgo originado por la conducta, activa u omisiva, en una gama que va desde la pura intencionalidad al dolo eventual, según el nivel de representación de la alta probabilidad de que se produjera esa grave situación de peligro" (entre d'altres, Sentència del Tribunal Suprem de 10 de novembre de 2015, ja esmentada).

4. I, finalment, un element valoratiu, integrat per la causació o possibilitat de causar danys substancials o un perjudici greu en els termes del precepte, i que és el que permet distingir entre el delicte i la infracció administrativa (sentències del Tribunal Suprem de 2 de març de 2012, ja esmentada, o de 13 de maig de 2013, n. 410/2013, rec. 1366/2012, ponent Andrés Martínez Arrieta; Sentència de l'Audiència Provincial de Cuenca de 8 de gener de 2015, Secció 1a, n. 1/2015, rec. 26/2014, ponent José María Escribano Lacleriga; de l'Audiència Provincial de Burgos de 4 de març de 2015, Secció 1a, n. 74/2015, rec. 11/2015, ponent Roger Redondo Argüelles) ${ }^{103}$.

\footnotetext{
102 Això suposa atribuir a l'Administració local la facultat de completar el tipus penal amb normes reglamentàries, la qual cosa no deixa de plantejar dubtes des del punt de vista del principi de legalitat penal.

${ }^{103}$ En aquest sentit, la Sentència del Tribunal Suprem de 13 de maig de 2013 recorda que el tipus exigeix un estàndard de gravetat, i amb referència a la Sentència del Tribunal Suprem 96/2002, de 30 de gener, expresa que "semánticamente grave es lo que produce o puede producir importantes consecuencias nocivas, lo que implica un juicio de valor (S. 105/99, 27 de enero). Para encontrar el tipo medio de gravedad a que se refiere el art. 325 del CP habrá que acudir, como dijo la citada sentencia 105/99, de 27 de enero, a la medida en que son puestos en peligro, tanto el factor antropocéntrico, es decir, la salud de las personas, incluida la calidad de vida por exigencia constitucional, como a las condiciones naturales del ecosistema". Concretament, i respecte al soroll, després de recordar, amb referència a la jurisprudència del Tribunal Europeu de Drets Humans i del Tribunal Constitucional, que aquest pot afectar els drets fonamentals a la integritat física i moral i, en casos de menor gravetat, la intimitat personal i familiar en l'àmbit domiciliari, conclou que "constituyen supuestos de especial gravedad cuando se trata de exposición continuada a unos niveles intensos de ruido. Se refiere, pues, a duración e intensidad del ruido". Partint d'aquestes consideracions, la Sala analitza l'afectació produïda en aquell cas concret, en el qual constata la reiteració dels fets, les continues visites de la inspecció, el trencament de precintes, l'afectació a la salut acreditada per la pericial psicològica i la producció d'uns nivells de soroll que superaven ampliament els límits permesos, "hechos que se reiteran en el tiempo y son prolongados durante horas, cada día, y días". Tot i així, la sentència també precisa que "la calificación penal de acto de contaminación no requiere una modificación de la sanidad física del perjudicado sino que la gravedad se rellena mediante la perturbación grave de las condiciones de calidad de vida". En els mateixos termes s'expressa també la més recent Sentència del Tribunal Suprem de 22 d'abril de 2015 (n. 244/2015, rec. 1574/2014, ponent Joaquín Giménez García), la qual, a més, desestima l'al·legació d'una de les defenses, que esgrimí el principi d'intervenció mínima del dret penal, afirmant que "no se puede estar más en desacuerdo con tal afirmación, en la medida que la contaminación acústica afecta a bienes sensibles relacionados con la salud de los ciudadanos y por tanto forma parte de los llamados bienes jurídicos difusos a los que el Código Penal presta especial atención”, referint-se a més a la transcendència de la
} 
No es requereix una lesió efectiva del bé jurídic protegit (tot i que l'article 325.1 també la preveu), és a dir, es tracta d'un delicte de perill ${ }^{104}$. Ara bé, aquest perill, a més de posar en risc el bé jurídic protegit, ha de tenir, d'acord amb el principi d'intervenció mínima, l'entitat i la gravetat suficients per justificar la intervenció del dret penal (en cas contrari, com hem dit, es tractaria d'una mera infracció administrativa). L'existència d'un resultat lesiu concret per a la salut de les persones suposa el concurs d'aquest delicte amb els corresponents de resultat (delictes de lesions dels articles $147 \mathrm{i}$ ss del CP; així, per exemple, la Sentència del Tribunal Suprem de 22 d'abril de 2015, ja esmentada).

D'altra banda, si bé en un primer moment fou considerat com un delicte de perill abstracte, posteriorment la jurisprudència s'ha inclinat per considerar-lo un delicte de perill hipotètic o potencial, com afirma l'esmentada Sentència de l'Audiència Provincial de Burgos de 4 de març de 2015, entenent com a tal "un híbrido «a medio camino entre el peligro concreto y abstracto» (Sentencia del Tribunal Supremo de 27 de setiembre de 2004)"105.

En l'àmbit penal, tal com ja hem vist en altres ordres jurisdiccionals, també s'ha plantejat el problema de la prova dels nivells de soroll i de la relació de causalitat entre el soroll i els danys a la integritat o salut de les persones. Des de la doctrina s'ha assenyalat que els requisits dels mesuraments són excessius, i s'ha proposat o bé que el mesurament no calgui en casos de soroll manifest, o bé que els mitjans siguin clars,

contaminació acústica en la jurisprudència del Tribunal Europeu de Drets Humans i del Tribunal Constitucional.

${ }^{104}$ Com afirma la Sentència del Tribunal Suprem de 2 de març de 2012, "La técnica más adecuada de protección del medio ambiente frente a las transgresiones más graves, que puedan constituir infracciones penales, es la de los delitos de peligro, pues la propia naturaleza del bien jurídico ««medio ambiente» y la importancia de su protección exige adelantarla antes de que se ocasione la lesión." La Sentència de l'Audiència Provincial de Burgos de 4 de març de 2015 precisa que "por lo tanto no es necesaria la prueba de un efectivo perjuicio para la salud de les personas, que, de producirse, llevaría al concurso del delito contra el medio ambiente con otro más de lesiones".

${ }^{105}$ La Sentència del Tribunal Suprem de 2 de març de 2012 també analitza aquesta qüestió i l'evolució jurisprudencial des d'aquest punt de vista, i constata l'opció del legislador, que renuncià a incorporar referències a la causació d'un perill concret. Tanmateix, "resultará imprescindible la rigurosa comprobación de que la conducta desarrollada ha resultado adecuada e idónea para poner en peligro el equilibrio de los sistemas naturales (cfr. STS de 3 de abril de 1995). Sentencias posteriores se han inclinado por considerar que se trata de un delito de peligro hipotético o potencial (STS num. 388/2003, de 1 de abril y 821/2004, de 24 de junio). De acuerdo con ello, es preciso acreditar que la conducta de que se trate, en las condiciones en que se ejecuta, además de vulnerar las normas protectoras del medio ambiente, es idónea para originar un riesgo grave para el bien jurídico protegido”. 
fàcils i econòmics, atès que l'obligació de mesurar pot arribar a convertir-se en un obstacle més pels afectats ${ }^{106}$.

Es poden trobar exemples clars d'absolució per defectes en els mesuraments i per considerar no acreditat el nexe causal entre el soroll i els danys en la Sentència del Tribunal Suprem de 28 de novembre de 2012 (n. 916/2012, rec. 558/2012, ponent Julián Sánchez Melgar) ${ }^{107}$, o en la més recent i esmentada Sentència de l'Audiència Provincial de Burgos de 4 de març de $2015^{108}$. Més favorable a l'acreditació del nexe causal entre

${ }^{106}$ En aquesta línia, cal resaltar la Sentència del Tribunal Suprem de 19 d'octubre de 2006 (n. 1091/2006, rec. 1973/2005 , ponent José Antonio Martín Pallín). Tot i que aquesta sentència fou posteriorment anul-lada per les de 26 de març i 23 d'octubre de 2015 (per haver condemnat l'acusat sense haver-lo escoltat, i haver vulnerat, per tant, la doctrina del Tribunal Europeu de Drets Humans), mereix una breu referència per la transcendència dels seus arguments. En aquell cas, en el qual s'utilitzaren, amb ple coneixement de l'autoritat municipal, uns sonòmetres no adequats, la Sala recorda que "en el caso de los delitos contra la seguridad del tráfico, si no consta la autorización, verificación y calibración de los alcoholímetros, no existe el menor inconveniente para condenar, valiéndose de otros elementos probatorios como el olor a alcohol, la deambulación insegura, la voz pastosa y la descoordinación en la expresión. Estos datos, de simple observación externa, han llevado a muchos Jueces y Tribunales a condenar sin obstáculo alguno", i afegeix que "en los delitos medioambientales es cierto que las mediciones tienen un papel más relevante pero no son la única fuente probatòria", i que "en este caso, los imputados, Ayuntamiento en la persona de su Alcalde y empresa, son los únicos que disponen de la posibilidad de medir el ruido [...] los denunciantes, están en absoluta desigualdad". La Sala, després de fer referència a la Sentència del Tribunal Europeu en l'assumpte Moreno Gómez contra España, conclou que "Nos encontramos, no ante un sólo indicio sino ante una acumulación reiterada de tantos indicios que resultaría temerario prescindir de ellos refugiándose en un dato negativo y evasivo que se limita a desvalorizar los aparatos medidores del ruido". En la més recent Sentència del Tribunal Suprem de 22 d'abril de 2015 (n. 244/2015, rec. 1574/2014, ponent Joaquín Giménez García), la defensa també al·legà que no constava el certificat de calibrat dels sonòmetres i que els policies no els sabien utilitzar. La sentència desestimà aquesta al·legació, i recordà que la sentència impugnada es basà en les declaracions dels policies, que afirmaren haver rebut formació en la matèria a l'acadèmia i que les medicions s'efectuaren correctament, i també en altres proves. Diferent és el cas de la Sentència de l'Audiència Provincial de Saragossa de 10 de novembre de 2015 (Secció 3a, n. 57/2015, rec. 42/2015), segons la qual, atesa la pluralitat de normes administratives aplicables, "existen una serie de posibilidades en cuanto a la medición que implican una variación en cuanto al nivel sonoro en su consideración de transgresión del límite reglamentario impuesto", i afegeix, a més, que, pel que fa a les medicions, "los propios agentes reconocen unánimemente en el plenario que, cuando las practican, lo hacen siguiendo un protocolo sin tener la necesaria cualificación", per la qual cosa "no pueden ser tenidas en cuenta a los efectos penales aquí pretendidos". La sentència afirma que "la administración no ha sancionado a la empresa acusada, le ha impuesto medidas correctores [...] que [...] se han ido haciendo [...] lo que nos lleva a considerar que el exceso de emisión por ruidos [...] no puede ser considerado como excesivo o grave", i afegeix, a més, que tampoc s'ha acreditat la relació de causalitat respecte a la patologia dels denunciants.

${ }^{107}$ La sentència considera que, en aquell cas, els informes mèdics no acrediten que els danys a la salut fossin conseqüència del soroll, i quant a les medicions, el seu caràcter esporàdic i el fet que els sonòmetres no estiguessin correctament calibrats fa que es considerin només orientatives.

108 Segons la Sala, tot i que, d'acord amb els testimonis dels veïns, els sorolls eren constants, les medicions i la constatació objectiva de la superació dels límites només es féu en tres ocasions, sense constatar una superació important, i tampoc consta acreditat que els danys a la salut dels denunciants tinguessin com a única causa el soroll, atesa la falta de contundencia dels informes forenses. 
el soroll i els danys resulta la Sentència del Tribunal Suprem de 17 de desembre de 2014 (n. 858/2014, rec. 959/2014, ponent Perfecto Andrés Ibáñez) ${ }^{109}$.

\section{CONCLUSIONS}

Tot i les importants implicacions que té el problema de la contaminació acústica, tant per a la salut com per a la qualitat de vida en la nostra societat, el seu tractament jurídic en defensa dels drets fonamentals que en poden resultar afectats encara pateix d'ombres i carències importants ${ }^{110}$.

Com hem vist en la nostra jurisprudència, cal atendre molt especialment tots els interessos implicats en cada cas (drets de les parts afectades, d'una banda, i interessos de la societat en el seu conjunt, de l'altra), i sempre cal cercar, com es desprèn de la jurisprudència del Tribunal Europeu de Drets Humans, un just equilibri, sense que es pugui optar per solucions reduccionistes que prioritzin automàticament uns interessos $o$ uns altres, atès que, si bé es poden trobar directament afectats drets fonamentals, el soroll pot obeir a causes molt diverses, en alguns casos de difícil solució sense elevats costos socials. Aquesta tensió entre els drets dels particulars afectats i els interessos de la col·lectivitat és una constant en aquesta matèria.

També hem vist com la legislació, esperonada per una jurisprudència atenta als drets dels particulars, ha intentat garantir també els altres interessos implicats en aquests problemes. En aquest sentit, resulten criticables tant solucions radicals procedents de la praxis judicial favorables als particulars afectats per soroll però que poden donar lloc a una clara inseguretat jurídica i a solucions injustes i inadequades socialment, com regulacions que només pretenen donar cobertura a actuacions de les administracions públiques injustificadament vulneradores de drets fonamentals.

En qualsevol cas, sí que cal evitar no sobrecarregar el particular, que ja pateix la immissió sonora, amb l'obligació de sufragar mesuraments constants i complexos, que poden arribar a suposar un autèntic fre en la legítima defensa dels seus drets. Tampoc se

\footnotetext{
${ }^{109}$ La sentència afirma que "una vez objetivados los datos relativos al ambiente de ruido en que los perjudicados se vieron constreñidos a vivir, con la consiguiente afectación del sueño, sí es posible hacer un diagnóstico dotado de un grado apreciable de fiabilidad, a partir de la constatación en los afectados de síntomas producidos en su momento, que fueran compatibles con las condiciones generadas por el establecimiento de referencia".

${ }^{110}$ De fet, cal no oblidar que tota la construcció jurisprudencial basada en drets de primera i segona generació obeeix bàsicament a la falta de previsió i protecció expressa del dret a una vida sense soroll.
} 
li ha d'imposar l'obligació de provar l'existència efectiva d'uns danys que en molts casos ja es pot entendre que deriven necessàriament de la situació viscuda ${ }^{111}$.

\section{BIBLIOGRAFIA}

ABERASTURI GORRIÑO, U. "Jurisprudencia ambiental del Tribunal Europeo de Derechos Humanos", en IeZ: Ingurugiroa eta zuzenbidea: Urtekaria = Ambiente y derecho: Anuario, n. 13, 2015, pp. 263-267. Recuperat l'1 de gener de 2016 a $<$ http://www.eitelkartea.com/dokumentuak/ABERASTURI.pdf $>$.

ALENZA GARCÍA, J.F., "La nueva estratègia contra la contaminación acústica y el ruido ambiental", en Revista jurídica de Navarra, núm. 36, 2003, pp. 65-120.

ALONSO SANZ, J. M., "La protección frente al ruido en el ordenamiento jurídico y, en especial, en la propiedad horitzontal". Recuperat l'1 de gener de 2016 de $<\mathrm{http}: / /$ www.vitoriagasteiz.org/wb021/http/contenidosEstaticos/adjuntos/es/89/94/38994.pdf>.

ANDRÉS ALONSO, F. L., "La jurisprudència constitucional y contenciosoadministrativa en materia de contaminación acústica", en Revista Xurídica Galega, núm. 40, 2003, pp. 61-92.

APODACA ESPINOSA, A. R., "La tutela del TEDH frente a la contaminación acústica continúa y se acentúa (comentario a la STEDH Deés C. Hungría, de 9 de noviembre de 2010)", en Revista Jurídica de Navarra, núm. 50, juliol-desembre 2010, pp. 211-228.

CALVO RETUERTO, J.; RUÍZ MARTÍNEZ, V., "Las inmisiones de ruidos en el Derecho Civil Catalán”, en Actualidad Jurídica (Uría \& Menéndez), núm. 22, abril 2009. Recuperat el 5 de maig de 2015, de $<$ http://www.uria.com/documentos/publicaciones/2201/documento/articuloUM.pdf?id= 3091>.

CASINO RUBIO, M., "La responsabilidad civil como forma inesperada de tutela de los derechos fundamentales (más sobre el ruido y su control constitucional)", en Revista Española de Derecho Constitucional, núm. 102, 2014 , pp. 353-386.

\footnotetext{
${ }^{111}$ Més encara quan, com disposa l'article 281.4 de la Llei d'enjudiciament civil, i com resulta del sentit comú més elemental, es troben exemps de prova els fets que gaudeixen de notorietat absoluta i general.
} 
FERNÁNDEZ EGEA, R. M. "Jurisprudencia ambiental internacional”, en Revista Catalana de Dret Ambiental, vol. III, núm. 1, 2012.

FERNÁNDEZ EGEA, R. M. "Jurisprudencia ambiental internacional”, en Revista Catalana de Dret Ambiental, Vol. IV, núm. 2, 2013.

FONT I LLOVET, T.; MIR PUIGPELAT, O., "Ruido y derechos fundamentales?”, en Derechos Fundamentales y otros estudios en homenaje al prof. Dr. Lorenzo Martín Retortillo. Vol. II., 2008, pp. 2035-2049.

GARCÍA ÁLVAREZ, G., "La evolución del régimen jurídico del ruido”, en Revista de Administración Pública, núm. 186, 2011, pp. 353-386.

GARCÍA GESTOSO, N.,“Contaminación acústica y derechos fundamentales. Protección y discrepancias en su tutela judicial”, en Foro, Nueva época, vol. 15, núm.1, 2012, pp. 109-134.

GARCÍA GESTOSO, N. "La delimitación y protección de nuevos contenidos de los derechos fundamentales: una aproximación desde el tratamiento de las injerencias sonoras", en Anuario da Facultade de Dereito da Universidade da Coruña, núm. 17, 2013, pp. 341-370.

GARCÍA URETA, A. "El ruido ante el Tribunal Europeo de Derechos Humanos. Otra llamada de atención a la jurisdicción contencioso-administrativa (y también al Tribunal Constitucional): Comentario a Martínez Martínez v. España, sentencia del TEDH de 18 de octubre de 2011", en Actualidad Jurídica Ambiental, núm. 7, novembre 2011, pp. 112. Recuperat el 5 de maig de 2015 de $<$ http://www.actualidadjuridicaambiental.com/comentario-el-ruido-ante-el-tribunaleuropeo-de-derechos-humanos-otra-llamada-de-atencion-a-la-jurisdiccion-contenciosoadministrativa-y-tambien-al-tribunal-constitucional-comentario-a-martinez/>.

GUERRERO LÓPEZ, J. A., "Defensa de daños por ruido", en Revista de la Asociación Española de Abogados Especializados en Responsabilidad Civil y Seguro, núm. 34, 2010. Recuperat el 5 de maig de 2015 de a dialnet.unirioja.es/descarga/articulo/3311683.

HERRERA DEL REY, J.J. "La Ley del Ruido: Ley urbanística de escasa aplicabilidad”, en Diario La Ley, n. 6295, 2005.

http://www.juristas-ruidos.org/. 
LAFUENTE BENACHES, M. M., "La contaminación acústica en las fiestas locales", en El Cronista del Estado Social y Democrático de Derecho, núm. 13, 2010, pp. 70-77.

LOPEZ RAMON, Fernando. "La ordenación del ruido", en Revista de Administración Pública, núm. 157, gener-abril 2002.

MAGRO SERVET, V., "La protección civil respecto a los excessos del ruido", en Revista de Jurisprudencia, núm. 2, 22 de novembre de 2012. Recuperat el 5 de maig de 2015 de http://www.elderecho.com/civil/proteccion-civil-respecto-excesosruido_11_483055001.html.

MARISCAL AGUILAR, C. M., "La protección del medio ambiente en la jurisprudencia del Tribunal Europeo de Derechos Humanos a través de la consideración del derecho al medio ambiente adecuado como parte del interés general en una sociedad democrática", en Medio ambiente y derecho: revista electrónica de derecho ambiental, número 24, febrer 2013. Recuperat el 5 de maig de 2015 de $<\mathrm{http}$ //huespedes.cica.es/gimadus/24/05.html $>$.

MARTÍ MARTÍ, J., “La prueba, en el proceso civil, del ruido, la inmisión y el daño causado", en Diario La Ley, núm. 7494, 22 d’octubre de 2010. Recuperat el 5 maig de 2015 de <http://www.bufetejmarti.com/ruidos-y-acustica/item/la-prueba-en-el-procesocivil-del-ruido-la-inmision-y-el-dano-causado> .

MARTÍN RETORTILLO BAQUER, L., "El ruido: reciente respuesta legal y jurisprudencial", en Foro Revista de Ciencias Jurídicas y Sociales [Facultad de Derecho de la Universidad Complutense], núm. 1, 2005, pp. 11-43.

MARTÍNEZ PÉREZ, E., “Jurisprudencia al día. Tribunal Europeo de Derechos Humanos. Contaminación Acústica", en Revista Catalana de Dret Ambiental, 8 de novembre de 2012. Recuperat el dia 5 de maig de 2015 de $<$ http://www.actualidadjuridicaambiental.com/jurisprudencia-al-dia-tribunal-europeode-derechos-humanos-contaminacion-acustica-2/>.

OFICINA UNIVERDE. Guía ruido. Recuperat el 5 de maig de 2015 de http://univerde.consorciouniverde.org/guia-ruido/.

PARRA LUCAN, M.A., "Jurisprudencia civil: La tutela civil frente a las inmisiones ilegítimas y la protección del dominio público natural", en Observatorio de políticas ambientales, 2011, pp. 289-312. 
PÉREZ SOLA, N., "El ruido y la integridad real y efectiva de los derechos fundamentales (reflexiones a propósito de la jurisprudencia del Tribunal Europeo de Derechos Humanos y el Tribunal Constitucional)", en Revista Española de Derecho Administrativo, núm. 156, 2012, pp. 173-200.

QUINTERO OLIVARES, G., i altres, Comentario a la reforma penal de 2015, 1a edició, Aranzadi, Pamplona, 2015.

SURROCA CASAS, P., "La protección civil frente al ruido", en Revista jurídica de la Comunidad de Madrid, núm. 26, 2008, pp. 103-141. Recuperat el 5 de maig de 2015 de http://huespedes.cica.es/gimadus/18/07.html.

URIARTE RICOTE, M., "La injerencia del ruido aeroportuario en la intimidad domiciliaria: la sentencia del Tribunal Supremo de 13 de otubre de 2008", en Diario la Ley, núm. 7222, 2009.

VÁZQUEZ IRUZUBIETA, C., Código Penal comentado, 1a edició, Atelier, Barcelona, 2015. 